\title{
ARTIG0S
}

\section{HISTÓRIA DA PALESTINA NOS TEMPOS DO NOVO TESTAMENTO (VI).}

\section{(Continuação).}

\section{§ 5. - Govêrno de Herodes: 1. Seguraryşa Interna e Defesa Externa.}

340. - Roma tolerava o instituto dos reis e príncipes aliados, porque êstes, geralmente em caráter vitalício, precediam a nomeação de governadores romanos, depois de preparados os respectivos territórios para serem definitivamente incorporados ao sistema provincial romano (n. 230). Ora, a incumbência principal dos governadores romanos era, evidentemente, a manutenção da paz e da ordem em suas respectivas províncias, e, conforme o caso, a defesa das fronteiras do Império (1). Esta última tarefa causou, aliás. desde o tempo de Augusto, a divisão entre províncias senatoriais e imperiais, sendo as primeiras - não guarnecidas por legiões - concedidas a governadores nomeados pelo Senado, as outras - onde se achavam aquarteladas uma ou mais legiōes - concedidas pelo imperador. Por esta mesma circunstância, já se pode concluir que as províncias senatoriais deviam ser aquelas que já se haviam incorporado definitivamente ao Império, enquanto as imperiais se situavam sobretudo na periferia do orbe romano e estavam, em conseqüência, mais expostas às incursões dos bárbaros e necessitadas de defesa contínua (2). Contudo, nas províncias desprovidas de legiōes recrutavam-se tropas auxi-

(1). - Ver, por exempio, U. Holzmeister 87. conforme o qual a primeira incumbência dos governadores romanos era: Res militaris et custodia ordinis publici. Aos soldados, com efeito, tocava igualmente o policiamento dos respectivos territórios, o ofício de verdugos, etc. Ver Suetônio, Caligula 32: Miles decollandi artifex; Mc. 6, 27: speculator $=0$ algoz, como em Sêneca, De Beneficentia 3, 25; De Ira 1, 18, 4, etc. 0 têrmo entrou também na linguagem rabínica, H. L. Strack-P. Billerbeck 2,12. Compare-se a atuação dos soldados no processo de Jesus (Mt. 27, 27-38. 54. 62-66, etc.), na prisāo de São Paulo em Jerusalém e Roma (Act. 21, 31-40; 22, 24-30; 24, 10-35; 28, 16), etc., e ver E. Schürer 2, 61 65; U. Holzmeister 88, etc.

(2) . - Estrabão, Geographica 17, 3, 25 (p. 840); Cássio Dión, Historia Romana 53, 12, 1-3 e 7; Suetônio, Augustus 47; B. Niese-E. Hohl 283; E. Schürer 1, 34716; J. Felten 2, 340-344; U. Holzmeister 82; J. Buchan, Augustus, London 1947, 145. De entre as províncias senatoriais só a África proconsular estava guarnecida por uma legião, para garantir o fornecimento regular 
liares, encarregadas de manter a paz interna e o policiamento dos respectivos territórios (3).

341. - De modo semelhante, os reis e príncipes aliados, sujeitos, por um lado, diretamente ao imperador (n. 225), mas que, por outro, não tinham legiões romanas à sua disposição (n. 235), encarregavam-se do alistamento e da manutenção de tropas próprias, sôbre as quais lhes competia o contrôle direto e completo (n. 228) . Como a estas tropas tocava a incumbência comum a tôdas as tropas do Império, começamos a tratar do govêrno de Herodes pelo exame das medidas por êle adotadas para a segurança e o policiamento dos territórios por êle administrados em nome de Roma, e para a defesa daquela parcela das fronteiras do Império que havia sido entregue à sua vigilância. Poderia êste parecer um assunto de somenos importância para nós. Para êle, era um assunto de interêsse vital, uma vez que, no dizer de José, depende das tropas a segurança dos reis, quando os povos cogitam de inovações (A. 17, 1, $1 \S 2)$, como, aliás, se pode ver concretamente na atuação do exército por ocasião das revoltas que se deram depois da morte de Herodes e que precederam a ascensão de Herodes Arquelau e de seus irmãos (A. 17, 9, $1 \S 206-3 \S 218$. 10, § $250-$ $10 \S 298$; G. $2,1,2 \S 5-3 \S 13.3,1 \S 39-5,3 \S 79)$.

342. - Parece, contudo que o exército nacional judaico, na época dos últimos hasmoneus, havia sofrido um forte declínio (4), e que seus esforços heróicos e prolongados nas diversas defesas de Jerusalém e do templo (nn. 14. 166-168), haviam sido antes provas de um heroismo religioso e patriótico, levado ao extremo, do que de um verdadeiro valor militar. Todavia, o próprio Herodes só conseguiu apoderar-se de seu reino com o auxílio de tropas romanas. e uma parte destas ficou, durante vários anos, aquartelada nos arredores de Jerusalém, para garantir a paz (nn. 166. 184. 188). Depois disto não ouvimos falar de tropas romanas na Palestina durante o govêrno de Herodes (n. 235). Assegurada a posse do país, vemos que o rei conseguiu impor a seu povo um periodo de cêrca de trinta anos de paz e de prosperidade, o que não lhe teria sido possível, sem a manutenção de um exército considerável

do trigo para Roma. Ver U. Holzmeister 88 e G. 2, 16, 4 § 383 . A Ásia e a Acaia são chamadas inermes por Tácito, Historiarum 2, 83.

(3). -.. U. Holzmeister 87; J. Felten 2, 342, etc. Tácito, Historiarum 1, 68 menciona na Récia alae cohortesque. Ver também G. $3,4,2 \S 66-68$, onde se mencionam coortes miliárlas e coortes enviadas pelos reis aliados. Coortes de itureus, estacionadas em diversas partes do Império, mencionamse em E. Schürer 2, 34043; na guarda de Marco Antônio, ib. 327.

(4). - W. Otto 151 . 
e bem aguerrido. Este, com efeito, garantia a paz interna e a defesa externa, e sem êle ter-lhe-ia sido impossível ausentarse, repetidas vêzes, do reino (n. 219), ou realizar tudo aquilo que de fato realizou (5). Veremos, com efeito, que o exército não só servia para policiar o país, ou para garantir a estabilidade do regime, mas ainda para fomentar a colonização interna do reino e a unificação e helenização do povo, o que não podia deixar de provocar a reação justificada do povo judaico (nn. 348, 394).

343. - I. Fôrças Armadas - As fôrças armadas de Herodes podem dividir-se, de um modo geraI, em três partes: a) a guarda pessoal do rei; b) o exército, que incluia as guarnições das fortalezas; c) e a reserva, constituída pelos veteranos e colonos militares. Encontramos a guarda real, que podia ser designada como o séquito do rei - $\theta \epsilon p a \pi \epsilon i a-$, desde o início do reinado de Herodes (6). Já Augusto lhe concedera quatrocentos gálatas, pertencentes até então a Cleópatra, como guarda

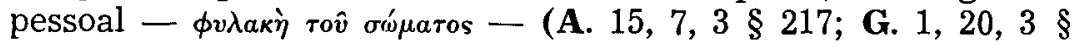
397 ), e pouco depois ouvimos que o rei participou, por meio

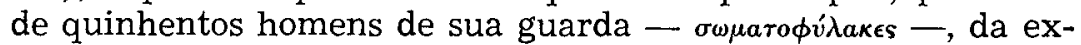
pedição de Élio Galo, prefeito do Egito, contra a Arábia Feliz (A. 15, 9, $3 \S 317 ;$ n. 244) (7), o que, ao mesmo tempo, nos dá lima idéia de seu número. Tratando-se, na expedição de Élio Galo, provàvelmente de cavalarianos (n. 244), podemos supor que se dividiam em tropas de cavalaria e de infantaria. Já na visita de Herodes a Augusto em Ptolemaide, em 30 a. C., mencionam-se cento e cinqüenta homens que o acompanharam (A. $15,6,7 \S 199$; n. 209). Tais guardas do rei, que serviam tam-

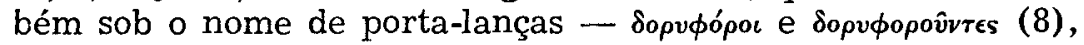
sempre se encontravam junto da pessoa do monarca, e executavam suas ordens imediatas (9). A guarda real distinguese, expressamente, do exército (A. 17, 8, $3 \S 198$; G. 1, 33, 9

(5). - E. Blkerman 51: Après la conquête la force armée garantissait l'obéissance due au vainqueur.

(6). - Therapeia emprega-se do séquito militar em Políbio, Historiae 5, 69, 6. Em geral designa a côrte e o séquito real, enquanto se distinguem das tropas. Ver E. Bikman 52s sôbre a casa militar dos selêucidas. Ver também W. Otto 84 e o n. 233.

(7). - Estrabão, Geographica 16, 4, 23 (p. 780) confirma a presença de quinhentos judeus na expedição.

(8). - G. $1,20,3 \S 397.33,7 \S 664 ;$ A. $15,7,3 \S 217 ; 16,7,1$ \& $182 ; 17,7,1$ $\$ 187.8,3 \S 198$. Ver E. Bikerman 52s e 2 Mac. 3, 24 onde aparecem doryphóroi em companhia do general Heliodoro.

(9). - Os doryphóroi acompanham o rel, quando êste tenta roubar o túmulo de Daví, e dols dêles são mortos por chamas saídas da terra, A. 16, 7 , $1 \S 182$. Encontram-se junto do rei no palácio de Jerusalém, e são encarregados da execução de seu filho Antipater, G. $1,33,7 \$ 664 ; A$. $17,7,1 \S 187$. 
672s), e parece ter sido constituída exclusivamente por estrangeiros, como já Daví e João Hircano se haviam cercado de tropas estrangeiras (n. 213). Com efeito, além dos gálatas mencionados, vemos figurar no entêrro do rei, além do exército, soldados trácios e germanos (G. 1, 33, 9 § 672; A. 17, 8, 3 § 198), e sabemos que entre os guardas do rei se encontravam também árabes (10).

344. - O exército, por sua vez, compunha-se das duas armas: a infantaria e a cavalaria, além da marinha (11). O têrmo $\sigma \tau \rho a \tau i \omega ́ \tau \eta$ s designava o soldado em geral (12), enquanto os

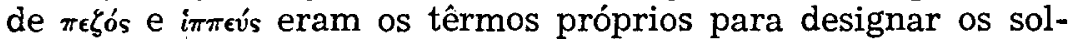
dados da infantaria e da cavalaria respectivamente (13). Encontramos, por vêzes, designados os soldados da infantaria como hoplitas, como no uso clássico grego (14), e fala-se também em tropas de armadura levar - коv์o (A. 14, 13, 9 § 362) (15), mas não sabemos se em José os dois têrmos ainda se referem, efetivamente, à distinção clássica entre tropas de armadura pesada ou leve (16) .

(10). - Nas passagens citadas de A. e G. mencinoam-se no entêrro do rei os doryphóroi, depois o destacamento dos trácios, os germanos e os gá. latas, e só depois o resto do exército. ' $\mathbf{E}^{\prime}$ preferível tomar os trácíos etc. como parte da guarda real, do que fazer dêles um corpo distinto dos guardas e do exército. Sôbre gálatas e trácios nos exércitos dos selêucidas ver E. Bikerman 57s. 60. 63, etc. Em A. 17, 3, 2 \&5-57; G. $1,29,3 \S 576 \mathrm{~s}$ fala-se de Corinto, da guarda pessoal do rel, e árabe de origem. Com êle são presos mais dois árabes, um, amigo de Sileu, ministro do rel nabateu, o outro, xeque de uma tribo. Este último talvez servisse a Herodes como chefe de outros guardas de sua tribo. Também o itureu Soemo se encontrava a serviço de Herodes, mas, ao que parece, não propriamente como militar, A $15,6,5 \S 185.7,4 \S$ 205. 4 \& 228s.

(11). - Mencionam-se Iado a Iado a infantarla e a cavalaria: G. 1, 16, 2 \$

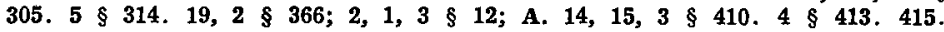
$5 \S 285$, etc. Ver Heródoto, Historiae 4, 134; Tucídides, Historiae 7, 61, $6 \S 431.8 \S 439$, etc. Sôbre marinha veja-se o n. 358.

(12). - G. $1,33,6 \S 660.8 \S 666 \mathrm{~s} .9 \S 670 ; 2,1,1 \S 3.33,5 \S 658 ; A .14,11$, 1; Aristóteles, Ethica Nicomachea 3, 8, 9.

(13). - A. 14, 15, $8 \S 439 ;$ G. $2,1,3 \S 12.3,4 \S 52.4 \S 58$, etc. Ver Homero, Ilias 8, 59; 11, 150s; Heródoto, Historiae 4, 134, etc.

(14). - G. $1,16,5 \S 314 ;$ A. $14,8,1 \S 128 ; 17,9,3 \S 215$, etc. Ver Heródoto, Historiae 7, 158; 9, 29; Tucídides, Historiae 1, 106, 2; 6, 22, etc. - Hoploph6roi: A. 14, 5, 5 § 425, etc. e Xenofonte, Cyropaedia 5, 4, 27; Eurípides, Phoenissae 789 , etc.

(15). - Ver P. Couissin, Les institutions militaires et navales (La Vie Publique et Privée des Anciens Grecs), Paris 1932, 25. 30s; E. Bikerman 55; J. Kromayer-G. Veith, Heerwesen und Kriegführung der Griechen und Römer, München 1928, 39, e Políbio, Historiae 10, 23, 2; Xenofonte, Memorabilia 3, 5, 27; Tito Lívio, Ab U'rbe Condita Libri, 36, 18, 2: levis armaturae.

(16). - Ver P. Couissin, ib. 24s. 30: 46-52. 75s; J. Kromayer-G. Veith, ib. 38s. 47-52. 
345. -- Como armas especializadas mencionam-se os arqueiros - ro ḱró - da Traconítide (17), e os seteiros montados

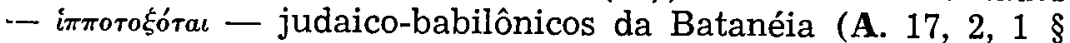
24), o que poderia sugerir que o arco fôsse a arma preferida dos habitantes do deserto, como, por exemplo, dos árabes, ou, então, daqueles, que haviam herdado seu uso dos persas e medas, como os judeus babilônicos da Batanéia, se os judeus em geral dêle também não usassem (18). Outra arma especiali-

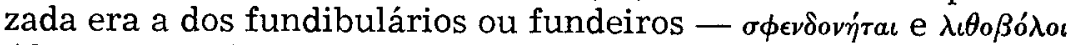
(A. 17, 10, $2 \S 259$ ), arma em que se especializavam sobretudo os sírios (G. $3,7,18 \S 211.19 \S 219$ ), que participaram, por exemplo, na conquista de Jerusalém, em 37 a. C., como tropas auxiliares dos romanos (A. 14, 16, 1 § 469; G. 1, 17, 9 § 346) (19). Não ouvimos falar em carros de guerra, nem em elefantes, mas É lícito conjeturar que o exército judaico da época dispunha dos outros recursos bélicos todos que então se conheciam, incluindo os da artilharia e da poliorcética, que deviam ser familiares às tropas herodianas desde os dias da conquista do reino $(20)$.

346. - Nada sabemos sôbre o recrutamento das tropas nacionais, o que é natural, diante do longo período de paz de que gozou a Judéia sob o principado de Augusto (21). Podemos su-

\footnotetext{
(17). - G. 2, 4, 2 § 58. Ver J. Kromayer-G. Veith, 1b. 54, e Tucidides, Historiae 6, 22 e 101, 6; 7, 60, 4; Heródoto, Historiae 7, 158, etc. Conforme o texto citado de José os arqueiros da Traconítide tam sob o comando de Grato, comandante da infantaria real (n. 353), Juntamente com um destacamento de sebastenos (n. 349), que também se dividiam em cavalaria e infantaria (n. 346). Supomos, por conseguinte, que os arqueiros em apreço combatiam a pé (cf. G. $3,4,2 \S 68$ ), distinguindo-se, precisamente, dos arqueiros montados, como em G. 2, 18, 9 § 500 .

(18). - A. 17, $10,2 \S 260$. Sóbre os árabes G. $3,4,2 \S 68.7,18 \S 211$. $19 \S$ 219. $27 \S 262$. Ver Lísias, Orationes 15, 6 (p. 144); Heródoto, Historiae 4, 46; 9, 49; Tucídides, Historiae 2, 96, 1; J. Kromayer-G. Veith, ib. 54, e E. Bikerman, 58, 60 sôbre os arqueiros montados nos exércitos dos selêucidas. Sôbre o arco entre os persas ver Estrabão, Geographica $15,3,1 \mathrm{~s}$ (p. 733s); entre os itureus E. Schürer $2,327$.

(19). - Sphendonêtai: Políbio, Historiae 5, 53, 9; Heródoto, Historiae 7, 158; Tucídides, Historiae 6, 22; Tito Lívio, Ab Urbe Condita Libri, 36, 18, 3: jaculatores, sagittarii, funditores. - Lithobólol de pessoas: Platão, Critias 119b; Filón de Bizâncio, Mechanica Syntaxis 4, 101c; de engenhos de guerra: Filón de Bizâncio, ib. 98a; Diodoro Siculo, Bibliotheca Historica 20, 48, enquanto o neutro lithobóla aparece em 1 Mac. 6, 51 e G. 5, 6, $3 \S 269$.

(20) . - No sítío de Jerusalém construiram-se três aterros, guarnecidos por tôrres, G. $1,17,8 \S 344 ;$ A. $14,15,14 \S 466.16,2 \S 473$. Mencionam-se 6rgana, mêchaná, mêchanêmata, e, da parte dos sitiados, minas, para anular o trabalho dos sapadores contrários. O assalto aos muros da cldade supōe, naturalmente, o conhecimento dos melos técnicos para êste fim, G. $1,18,1 \S 348-351$; A. $14,16,2 \S 473-476$. Ver, em geral, J. Kromayer-G. Veith, tb. 209-245, e, sôbre os selêucidas, E. Bikerman 62s e 1 Mac. 6, 20. 51, etc.

(21). - Sôbre o recrutamento no relno dos selêucidas ver E. Bikerman 68-90, nos dos ptolomeus ib. 78 .
} 
por, todavia, que em grande parte se tratava de voluntários e de descendentes de veteranos (n. 398). Não sabemos, igualmente, se o efetivo das tropas judaicas estava limitado por Roma, o que sempre era possivel (22), mas é certo que o exército ativo contava com vários milhares de homens também em tempo de paz (23), como provam, por exemplo, os trezentos oficiais executados por ocasião das desavenças de Herodes com seus filhos Alexandre e Aristóbulo (G. 1, 27, 4 § 544- - 6 §50; A. $16,11,4 \S 373-7 \S 394)$. Quando, por ocasião do levante contra Arquelau, sucessor de Herodes na Judéia, os revoltosos contavam com a adesão da maioria das tropas reais, três mil sebastenos (n. 349), entre cavalaria e infantaria, continuaram fiéis ao novo soberano (G. $2,3,4 \S 52 ; \mathbf{A} .17,10,3 \S 266$ ). Segue-se daí, que os rebeldes contavam com um número superior a três mil homens, e que o efetivo conjunto das tropas reais era, na ocasião, superior a seis mil, devendo acrescentar-se, ainda, a guarda real e as guarnições das fortalezas, que continuavam tiéis ao regime, e não terão deixado seus postos (24). No caso de uma guerra, os arsenais judaicos podiam fornecer armas para mais alguns milhares de homens. Sabemos, assim, que Herodes depositou armas para dez mil homens só na fortaleza de Masada (G. 7, 8, $4 \$ 299$ ), e que os rebeldes, na época de Arquelau, se armaram nos arsenais de Sefóris da Galiléia (G. $2,4,1 \S 56$; A. $17,10,5 \S 271 ;$ n. 311 ).

347. - Durante todo o govêrno de Herodes seu exército se compunha de tropas nacionais e estrangeiras (25), abstraindo das tropas romanas que o ajudaram a conquistar seu reino, e que estavam temporàriamente sujeitas a êle (n. 163), ou, então, entregues ao comando conjunto dêle e do legado Caio Sósio (n. 166) (26). E' natural que durante a campanha para a conquista do reino, de 40-37 a. C., seja mais freqüente a menção de tropas judaicas pròpriamente ditas, quando se tra-

\footnotetext{
(22). - W. Otto 56. Ver A. 18, 7, $2 \S 251$, onde Agripa I acusa a Herodes Antipas diante de Caligula por ter em seus arsenais armas para 70.000 homens, o que êle nāo nega.

(23). - W. Otto 56 .

(24). - Ver a atitude de seus comandantes no caso de Sabino procurador das finanças da província da Síria n. 377. Aquiab, contudo, comandante de uma das fortalezas da capital, provàvelmente do palácio (n. 377), participa ativamente na repressáo dos distúrbios que se deram depois da morte de Herodes, G. 2, 4, I $\$ 55.5,3 \S 77 ;$ A. $17,10,4 \S 270.10 \S 297$.

(25). - Diz-se expressamente que Herodes, em 40/39 a. C., angariou em Ptolemaide tropas estrangeiras e nacionals, G. 1, 15, $3 \S 290$; A. 14, 15, $1 \S 394$. Ver o n. 155 sôbre o sentido de homóphyloi. Em G. 1, 4, 5 § 93 mencionam-se mercenários ao lado de tropas judaicas, em 1, 15, $6 \S 301$ ao lado de tropas romanas e judaicas.

(26). - 0 último fato afirma-se expressamente em G. 1, 17, $9 \S 346$; A. 14, 16, $1 \S 469$.
} 
tava de provar a adesão do povo pela concorrência às armas (27), como é evidente, do mesmo modo, que tôdas as tropas de Herodes se designassem simplesmente como fôrças judaicas, quando se tratava de distingui-las das fôrças inimigas, estrangeiras ou nacionais, como, por exemplo, dos nabateus, em 32 a. C. (28) .

348. - O exército todo era designado pelo nome de $\sigma \tau \rho a-$

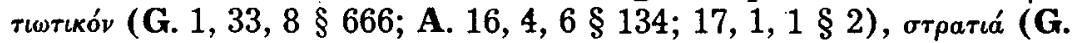

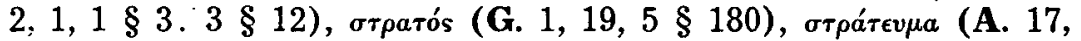
$10,3 \S 266.8,4 \S 202$ ) ou $\delta$ v́vaus (G. $1,33,9 \S 673 ;$ A. $15,7,10$

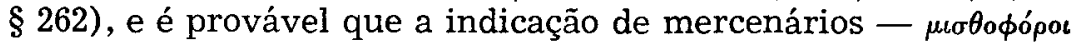

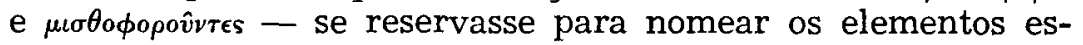
trangeiros do exército (29). De entre êstes últimos conhecemos, por exemplo, os oitocentos libaneses, angariados por Herodes em sua campanha pela conquista do reino (G. $1,17,3 \S$ 329 ; A. 14, 15, $11 \S 452$; n. 165), além dos estrangeiros que faziam parte da guarda real, como gálatas, trácios, germanos e nabateus (n. 343). Estas tropas estrangeiras talvez servissem no exército judaico com suas armas características, e sob o comando de seus chefes nacionais (30). O grande número de tropas estrangeiras no exército de Herodes prova-se ainda pela circunstância de as colônias de veteranos de Gaba e Hésebon (n. 394) se acharem entre as primeiras cidades pagãs devastadas pelos judeus no comêço da guerra de 66-70 d. C. (G. 2, $18,1 \S 458 \mathrm{~s})$ (31).

349. - Dentre as tropas nacionais merecem menção especial os sebastenos, os arqueiros da Traconítide, e os seteiros montados judeu-babilônicos da Batanéia, já mencionados ( $n$. 345). Os sebastenos parecem ter constituído um corpo de elite dentro do exército real, a cujo lado se mencionam (G. 2, 5, 2

(27). - Mencionam-se judeus em G. 1, 15, $3 \S 291.4 \S 294.17,6 \S 355$; A. 14, $5,2 \S 400$, etc.; idumeus em G. $1,15,4 \S 293$; A. 14, 15, $5 \S 398$; gallleus em A. 14, 15, $1 \S 391$. Ver, contudo, o n. 155.

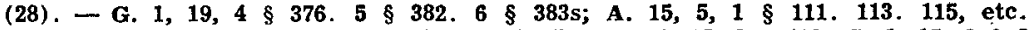

(29). - A. 14, 13, 9 \$ 361 ; G. $1,4,3 \S 88$. Em A. $14,15,3 \S 410 ;$ G. $1,15,6 \S 301$ fala-se em dez coortes, cinco romanas e cinco judaicas, misturadas com mercenários. Ver também E. Bikerman 69.

(30). - Tito Lívio, Ab Urbe Condita Libri, 38, 17, 3 menciona vasta scuta, praelongi gladii como armas dos gálatas. Conforme Aplano, Historia Romana $11,1,32$ combatiam revestidos de armadura. Os trácios eram peltastas, soldados armados à ligeira, E. Bikerman 58 e Xenofoute, Memorabilia $3,9,2$, conforme o qual a peltê, o escudo pequeno, e o akóntion, o dardo, eram as armas típicas dos trácios. Em 2 Mac. 12, 35 menciona-se a cava. larla dos trácios. Quanto aos chefes indígenas ver E. Bikerman 72 e 1 Mac. 10, 37; 2 Mac. 8, 20.

(31). - W. Otto 56s, nota. Hésebon, nesta ocasião, já parece ter stdo autônoma, ver n. 390 . 
$\S 74 ;$ cf. $2,3,4 \S 54.4,2 \S 58.3 \S 63$ ) (32). O mais natural é supor que se tratasse de tropas recrutadas em Sebasté-Samaria, colônia militar de Herodes (n. 391) (33), e não de uma tropa que tivesse recebido seu nome de Augusto-Sebastós (34). O fato é bastante sugestivo, uma vez que os sebastenos e os arqueiros da Traconitide provinham de territórios não pròpriamente judaicos. A inimizade entre samaritanos-sebastenos e judeus tornara-se proverbial (n. 307), e a Traconitide, território pròpriamente árabe, só passara às mãos de Herodes em $24 / 3$ a. C. (n. 266). Ainda que tomemos em conta a transplantação de três mil colonos idumeus para a Traconítide (A. 16, $9,2 \S 285.3 \S 292 ;$ n. 391), sempre lidamos com conterrâneos mais chegados de Herodes (n. 89), com os quais êle certamente podia contar mais do que com os judeus pròpriamente ditos.

350. - Em todo caso, três mil sebastenos e os arqueiros da Traconítide estão entre as tropas que permaneceram fiéis à corôa depois da morte de Herodes (G. 2, 3, 4 § 52. 4, 2 § 58; A. $17,10,3 \S 266$ ). Os judeus babilônicos da Batanéia, por sua vez, que tinham todos os motivos para se mostrar fiéis à monarquia, diante dos privilégios de que gozavam (n. 392), estavam, além disto, isolados no meio de uma população pagã em sua maioria, e podiam ser considerados dignos de confiança (35). O fato da presença destas tropas não pròpriamente judaicas, ou, então, de absoluta confiança, quando eram judaicas, é tanto mais notável, quanto também a guarda pessoal do rei parece ter sido constituída exclusivamente por estrangeiros. Note-se que os sebastenos reaparecem, mais tarde, quando se trata de enviar expedições punitivas contra os judeus, e são êles os que causam distúrbios depois da morte de Herodes Agripa I, por êste rei ter favorecido demasiadamente os judeus de Cesaréia (36).

(32). - Parte, ao menos, dos sebastenos estava aquartelada em Cesaréia, G. 2, $12,5 \S 236$; A. $19,9,1 \S 356-359.2 \S 361-366$. Em A. $17,10,3 \S 266$ (passagem paralela de G. $2,3,4 \$ 52$ ) omite-se 0 nome dos sebastenos, mas afirma-se que Rufo e Grato tinham do seu lado e do de Arquelau a parte mais forte do exército de Herodes.

(33). - W. Otto 56, nota; H. St. J. Thackeray 2, 342; A. H. M. Jones 78; E. Schürer 2, 51-53. 3, 126, etc.

(34). - U. Holzmeister 97, que os Identifica com a speira Sebasté de Act. 27, 1, estacionada precisamente em Cesaréia. Aquela, de fato, podia ter recebido o direito de usar o nome de Augusto, como acontecia com outras coortes e com legiōes inteiras. Numa inscrição da Auranitide menciona-se um éparchos... speirês Angoustês, ib., e W. Dittenberger, Orientis Graeci Inscriptiones Selectae I, Leipzig 1903, 632, n. 421. H. St. J. Thackeray 2, 343 sugere que o título tenha sido cohors Augusta Sebastenorum; cf. E. Schürer 2,53 .

(35). - A. H. M. Jones 79.

(36). - Ver, por exemplo, a expedição de Cumano em G. 2, 12, 5 \& 236; A. 20, 6, I $\S 122$. Sôbre Agripa I e os sebastenos ver A. 19, 9, 1 \ 356-2 $\S 366$. 
351. - Não sabemos se o exército de Herodes estava organizado à maneira romana ou à grega (37), umà vez que só conhecemos os títulos dos oficiais, que nem sempre são uniformes, e, por conseguinte, nem sempre revelam a posição exata ocupada por seus detentores (38). E' possivel, outrossim, que os secretários gregos de José (nn. 46. 57) tenham tomado certas liberdades no emprêgo dos têrmos militares. Ouvimos falar, todavia, de coortes judaicas ao lado de coortes romanas (A. $14,15,3 \S 410 ;$ G. $1,15,6 \S 301$ ), onde pode tratar-se, ou de uma expressão menos exata, ou da tentativa de Herodes de introduzir em seu exército a organização romana, como já tentara fazer Antíoco IV no seu, e como fará, mais tarde, José no exército sujeito às suas ordens na Galiléia (39). Por outro lado, menciona-se uma coorte judaica a serviço de Arquelau (n. 235),

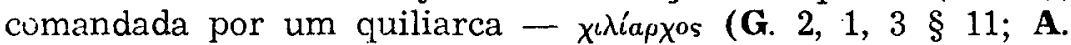
$1 \%, 9,3 \S 215)-$, o que parece refletir o sistema das coortes miliárias, próprias das tropas auxiliares (40). Contudo, assim

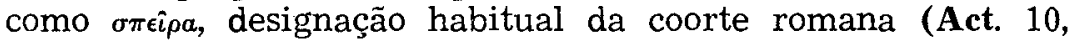
$1 ; 21,23 ; 27,1$; Mt. 27, 27), pode significar uma companhia de

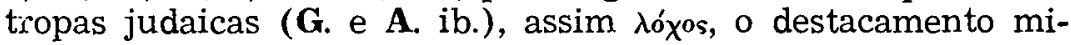
litar de tamanho variável, pode designar uma coorte romana (G. $2,4,3 \S 63$ ) .

352. - Conhecemos, todavia, alguns nomes de comandantes das tropas herodianas, e mencionam-se títulos de oficiais inferiores. No início do reinado de Herodes encontramos um

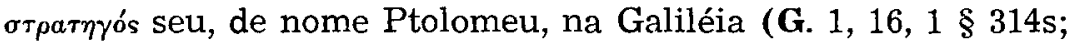
A. $14,15,1 \S 431 \mathrm{~s} ; \mathrm{n} .161$ ), mas êste título é genérico demais para que dêle possamos concluir a organização do exército

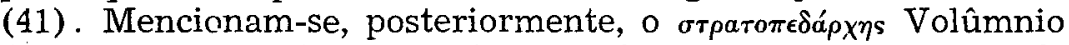
(G. $1,27,1 \S 535)$, que pode ter sido o comandante-em-chefe

Ver o n. 275, ondese menciona a possibilidade de soldados sebastenos terem atuado na Paixão de Jesus.

(37). - Ver, em geral, as obras de J. Kromayer-G. Veith e P. Couissin, citadas na nota 9 .

(38). - W. Otto 57; E. Bikerman 51.

(39). - E. Bikerman 56s, baseado em Políbio, Historiae 31, 3, 3, que menciona cinco mil homens armados à romana. Quanto a José, ver G. 2, 20,7 § $577-582$ e 3, 5, 1 § $70-8 \S 109$, onde manifesta sua admiração pela organização e disciplina romanas.

(40). - U. Holzmeister 87. Ver G. 3, 4, $2 \S 67$, onde se distinguem coortes de mil homens e coortes de seiscentos homens com 120 de cavalaria. Também ib. § 68 as tropas auxiliares, enviadas pelos reis aliados, são tôdas divisíveis por mil. Ver E. Gabba, Iscrizioni (n. 81) 87, onde se cita uma inscrição referente a uma coorte miliária. Uma coorte e um quiltarca mencionam-se também em Jo. 18, 3. 12; tribunos em Mc. 6, 21; Act. 21, 31, etc.

(41). - E. Bikerman 51. 64 . 


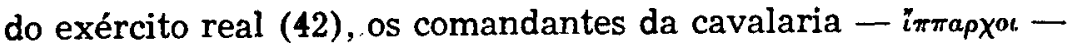
Jucundo e Tirano (G. 1, 26, 3 § 527) (43), bem como Rufo e Grato, no comando da cavalaria e da infantaria dos sebastenos respectivamente (44). Durante os distúrbios que se seguiram à morte de Herodes aparecem o chanceler Ptolomeu e Aquiab, primo-irmão de Herodes, no comando de expedições militares (45). Encontramos, ainda, o título de raḱiapxos, comandante de

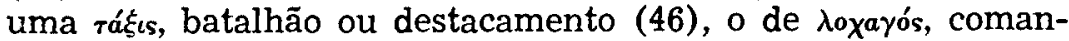
dante de um lóxos, destacamento de infantaria (47), o de

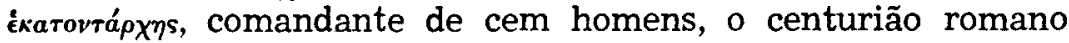

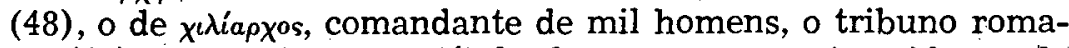
no (49), enquanto que o título de $\dot{\eta} \gamma \epsilon \mu \omega ́ v$ parece ter sido usado para designar qualquer oficial superior (50).

353. - Estes diversos nomes gregos, contudo, não eram apenas adaptações de títulos aramaicos, ou traduções de títulos latinos, mas nomes atualmente usados, como prova o fato de vários dêles terem passado para o aramaico (51). O fato pode igualmente supor-se em vista da grande porcentagem de es-

(42). - A. H. M. Jones 77. Strat6́pedon pode significar um acampamento, um exército acampado, simplesmente um exército ou uma legião romana, A. Bailly, Dictionnaire Grec-Françafs, Paris 1950, 1800. Conforme H. St. J. Thackeray 2, 255 Volúmnio era um military tribune, o estratopedarca Tirânio Prisco, mencionado em G. 2, 19, $4 \S 531$, um camp-prefect, enquanto, conforme A. Bailly, ib., êste último era o commandant d'une armée. Segundo G. Ricciotti, Flavio Giuseppe 2, 169 e 346 o cargo de ambos era o de commandante degli accampamenti. O mencionado Volúmnio deve, provàvelmente, distinguir-se do epftropos Volúmnio, que assiste, em Belrute, ao processo contra Alexandre e Aristóbulo, filhos de Herodes, G. $1,27,2 \S 538.3 \S 542 ;$ A. 16, $9,1 \S 280.10,8 \S 344.11,3 \S 369$. Ver o n. 255 e S. St. J. Thackeray $2,255$.

(43). - Trata-se, por conseguinte, de dois comandantes de cavalaria, como em Atenas. Ver P. Couissin, ib. 33; J. Kromayer-G. Veith, ib. 52; Xenofonte, Hipparches 1, 2. Outro hiparca Jucundo encontra-se em Cesaréia, em 66 d. C., G. $2,14,5 \& 291$.

(44). - Ver o n. $349 \mathrm{~s}$, e G. $2,3,4 \S 52.4,2 \S 57.59 .3$ \& 63 s. $5,2 \S 74$; A. 17 ,

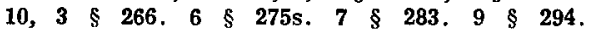

(45). - Ptolomeu é mencionado em G. 2, 4, $3 \$ 64 ;$ A. 17, 10, 7 \$ 284. A seu tempo tratar-se-á da identidade dêste Ptolomeu com o chanceler de Herodes e o irmão de Nicolau de Damasco. Sôbre Aquiab ver os nn. 87, 34624. 377.

(46). - G. $1,19,3 \S 369.23,5 \S 461.24,7 \S 491.33,9 \S 673 ; 3,5,4 \S 87 ;$ A. 17 , $8,3 \S 199$, etc. Ver J. Kromayer-G. Veith, ib. 49 e Heródoto, Historiae 6, 111; Tucídides, Historiae 5, 68, 1; Xenofonte, Cyropaedia 8, 1, 10, etc.

(47). - A. 17, 8, $3 \$ 199$. Ver J. Kromayer-G. Veith, ib. 34s; P. Couissin, ib 24. 33; Tucídides, Historiae 5, 66, 3 e 68, 3; Heródoto, Historiae 3, 57; Xenofonte, Anabasis $3,1,12$, etc.

(48). - G. $2,4,3 \S 63 ; 3,5,3 \S 87 ;$ A. $17,10,7 \S 282$. Ver hekatóntarchos em Act. 10, 1. 22; Mt. 8, 5; o latinismo kentyriôn Mc. 15, 39. 44s, etc.

(49). - G. $2,1,3 \S 11 ; 3,5,3 \S 87 ; A .17,9,3 \S 215$. Ver o n. 351 .

(50). - G. 1, 24, $7 \S 491.27,4 \S 546.6 \S 550.33,9 \S 673 ;$ A. $16,4,6$ \& 134 . $11,5 \S 386.6 \S 393$. Ver $W$. Otto 56 , nota; E. Blkerman 64-67. Grato, comandante da infantaria real dos sebastenos, G. $2,3,4 \S 52$, é simplesmente chamado seu hegemôn, ib. 4, 2 \& 58 .

(51). - W. Otto 56, nota. 
trangeiros no exército de Herodes, o que também sugere que a linguagem militar tenha sido o grego, familiar a muitos elementos estrangeiros da guarda de Herodes (52). Por outro lado, vários dos nomes próprios dos comandantes já mencionados sugerem que se tratava de oficiais de instrução romanos. Entre êles estão o estratopedarca Volûmnio, e os comandantes Rufo e Grato, enquanto que o comandante de cavalaria Jucundo, apesar de seu nome genuinamente latino, não pode ter sido cidadão romano, porque Herodes, sem mais, manda submetê-lo à tortura (G. 1, 26, $3 \S 527$; A. 16, 10, $3 \S 314 \mathrm{~s}$ ) (53) . Parece, por conseguinte, que Roma, apesar da autonomia do rei em assuntos militares, soube exercer, dêste modo, um certo contrôle também na administração militar superior da Judéia (54), a não ser que o próprio Herodes quisesse introduzir a disciplina militar romana em seu exército, como ficou dito acima (n. 351). Neste caso podemos ver nos romanos mencionados uma espécie de caudilhos militares assalariados por Herodes (55).

(52). - W. Otto, ib. O grego era familiar aos trácios e gálatas. Os quatrocentos gálatas doados por Augusto (n. 213), haviam servido no exército egípcio, onde certamente se falava o grego. G. 3, 5, 4 \& 92 refere-se às legióes romanas, onde se usava o latim. Não se pode concluir dai, com U. Holzmeister 97, que as coortes auxilliares da Judéia usassem igualmente aquela língua.

(53). - W. Otto 57. Aliás, também Rufo não designa necessàriamente um oficial romano, porque o nome era usado também pelos judeus. Ver Mc. 15, 21: Rufo, filho de Simão de Cirene, e J.-B. Frey, Corpus Inscriptionum Judaicarum I, Città del Vaticano 1936, 102-104, nn. 145 e II, ib. 1952, 34, n. 774. Com estas reservas sôbre os nomes de Jucundo e Rufo devem ler-se as palavras de St. Perone 105: It is noticeable that when Josephus mentions any particular category, e. g. ministers, Masters of the Florse or tutors to the royal children, the holders of the office are named in pairs, one Greek and one Roman. Herod wanted, it seems, to keep the balance between Greek and Roman influence. Vimos que Jucundo, um dos comandantes da cavalaria, não podia ser cidadão romano, e Rufo, um dos comandantes dos sebastenos, não o era necessảriamente, assím como o nome de Tirano, companheiro de Jucundo, era usado também por judeus J.-B. Frey, ib. II, 18, n. 753 . O Tirânio Prísco de G. 2, 19,4 $\S 531$ era romano. Tođavia, é bastante verossímil que Gemelo, um dos educadores dos príncipes herodianos (n. 253), tenha sido romano, responsável por sua cultura latina, como Andrômaco, seu companheiro, o era por sua cultura grega, W. Otto 87. Por outro lado, o nome de Gemelo era igualmente usado por judeus, J.-B. Frey, ib. II, 178, n. 993 e 188, n. 1026.

(54). - W. Otto 57.

(55). - A. H. M. Jones 77: Names are not a sure test of nationality, but it is not improbable that Herod, who had a great respect for the Roman army, may have employed Itallan milltary experts; these men were, it is clear, private adventurers and had no official connexion with the Roman government. The army would seem to have been organized on the Roman model; many units were taken over directly into the imperial army on the dissolution of the kingdom. - Se a cessação do reino se refere à divisāo do mesmo depois da morte de Herodes e da deposição de Arquelau, as tropas judaicas podiam continuar como tropas auxilia- 
354. - Não há dúvida, contudo, de que Herodes, como os reis helenísticos em geral, era o comandante supremo de direito de tôdas as fôrças armadas do país, e que, de fato, se comportava como tal. Quando da nomeação, em 12 a. C., de seus filhos Antípater, Alexandre e Aristóbulo, como sucessores seus (n. 238), o rei, em sua proclamação ao povo, insiste expressamente no fato de êle mesmo continuar a reter a suprema autoridade sôbre todos os funcionários do reino, e sôbre os oficiais do exército (G. $1,23,5 \S 460$ s; A. 16, 4, $6 \S 134$ ) (56). E' verdade, que nada lemos sôbre um juramento de fidelidade prestado por suas tropas a Herodes, mas vimos que no juramento que tôda a nação judaica teve que prestar a Augusto, por uma hábil manobra do rei, também se jurou fidelidade aos seus interêsses (n. 245). E' lógico supor, que as tropas estivessem obrigadas ao mesmo juramento (57), porque vemos que logo depois da morte do rei, e apenas conhecida a nomeação de Arquelau como seu sucessor, tanto o povo, quanto as tropas com seus oficiais prometem a evvoca ao novo soberano (G. 1, 33, 8 § 670; $2,1,1 \S 3$ ) (58). Por outro lado, é apenas natural supor que já Herodes tivesse introduzido o costume helenístico de exigir um juramento de fidelidade de suas tropas para com a pessoa do rei (59).

355. - Só conhecemos uma ocasião em que parte do exército cogitou em opor-se às disposições do rei, isto é, quando

res romanas, sem necessàriamente fazer parte do exército imperial; se se refere, pelo contrário, a morte de Agripa $I$, deve tratar-se da ameaça de transferência dos destacamentos de cesareanos e sebastenos com as cinco coortes para o Ponto, e sua substituição por partes das legiões romanas estacionadas na Síria, A. 19, 9, 2 \& 264s. Esta passagem, contudo, sugere a distinção entre as tropas auixiliares judaicas e as tropas regulares romanas, e não necessàriamente que aquelas fizessem parte destas, como quer U. Holzmeister 98, o qual, além disto, afirma que as primeiras foram enviadas ao Ponto por Cláudio, enquanto ib. $148 \mathrm{~s}$ diz corretamente, conforme A. ib. $\S 364-366$, que elas obtiveram a revogação da ordem imperial. Conforme ib. $\$ 366$ foi Vespasiano quem as transferiu da Judéia. Não se mencionam na distribuição das legiões em $G$. $7,1,3 \S 17-20$.

(56). - Ver também E. Bikerman 13. 52.

(57). - W. Otto 56.

(58). - Em A. 17, 8, 8 § 195 não se faz menção do povo, nem ib. 4 202. Sôbre a eúnoia ver ainda G. $1,33,8 \S 667$ e o n. $245 \mathrm{~s}$, e A. $15,7,9 \S 256$, onde se diz que Costobar quis transferir sua eúnoia de Herodes para Cleópatra.

(59). - W. Otto 95s; E. Bikerman 97. Ver Justino, Epitoma Historiarum Philippicarum 35, 2, 3: Sed et milites paterni favore juvenis accensi prioris sacramenti religionem novi regis superbiae praeferentes signa ad Demetrium transferunt. - Estrabão, Geographica 12, 3, 31 (p. 557) menciona o juramento com a menção da fortuna do rei, com o que se compare - juramento a ser prestado, sob a invocação da fortuna do rei Selêuco, pelos cidadãos e as tropas de Sípllo, em E. Bikerman 97. 255, conforme W. Dittenberger, Orientis Graeci Inscriptiones Selectae I, Lipsiae 1903, 371, n. 229. 
em Cesaréia se propalou o resultado do processo de Beirute, condenando à morte Alexandre e Aristóbulo, filhos de Herodes (nn. 243. 255). A intervenção indiscreta do veterano Tero a favor dos imputados fêz com que se procedesse a uma investigação em regra, cujo resultado foi a descoberta de que parte das tropas e dos oficiais não estava de acôrdo com o resultado do processo (G. $1,27,4 \S 546$; A. $16,11,4 \S 375-378$ ). Todos os imputados, incluindo trezentos oficiais, foram condenados e linchados por uma assembléia do povo (60). Contudo, já em ocasião anterior refere-se que Alexandre havia conspirado com oficiais do exército (G. 1, 24, $7 \S 491$; A. 16, 8, 1 § 234) (61). Entende-se, todavia, que Herodes pudesse, em carta dirigida a seus soldados, pouco antes de sua morte, agradecer a fidelidade e lealdade por êles dedicadas à sua pessoa, e pedir que as dedicassem do mesmo modo a seu filho Arquelau (A. 17, 8, 2 § 194s) (62) .

356. - Em vista dêste fato, e, ainda, em vista da importância do exército como fator estabilizador de seu regime (n. 342 , compreende-se que o rei não sòmente o tratasse com de$\mathrm{f} \in$-rência especial, mas ainda compartilhasse de suas fadigas, mesmo na velhice, sempre dentro das melhores tradições helenísticas (63). Com efeito, desde o comêço, como governador da Galiléia, vemo-lo presente em pessoa em tôdas as campanhas por êle empreendidas, como na campanha contra os bandidos da Galiléia (n. 103); na retirada para Masada (n. 133); na campanha pela conquista do reino (nn. 154-168), onde até saiu ferido (A. 14, 15, 12 § 456; G. 1, 17, 4 § 332); na campanha de Samósata (n. 163); na primeira guerra contra os nabateus (n. 195s), etc. Ainda sexagenário vemo-lo à frente de suas tropas em nova guerra contra êstes mesmos nabateus (A. 16, 9, 2 $\S 282 \mathrm{~s})$.

357. - Referências ocasionais nos revelam sua solicitude pelo bem-estar de seus soldados, suas providências quanto às provisões e acampamentos de inverno (A. 14, 15, 4 § 417. 419; n. 159), e, uma vez, durante a campanha pela conquista do reino, menciona-se o pagamento do soldo de 150 dracmas a cada soldado, e de somas maiores aos oficiais (n. 159), bem como o

\footnotetext{
(60). - G. $1,27,4 \S 544-6 \S 550 ;$ A. $16,11,4 \S 373-7 \S 394$. Nicolau de Damasco, De Vita Sua, Fragmento 5 (ed. C. Müller, Fragmenta Historicorum Graecorum III, Parisiis 1883, 352) menciona a corrupção de todo o exército e dos funcionários réglos por parte dos acusados como parte das calúnias de Antípater contra seus irmãos.

(61). - Ver W. Otto 110.

(62). - Fala-se no texto em pístis e eúnoia, enquanto que em G. 1, 33, $8 \S 667$ só se apela para a eúnoia para com Arquelau.

(63). - E. Bikerman 13. 52; W. Otto 110 .
} 
fato de seu irmão Feroras se encontrar à frente do serviço de intendência (n. 160). Ainda pouco antes de sua morte o rei manda distribuir 50 dracmas a cada soldado, e somas consideráveis aos oficiais (G. $1,33,5 \S 658 ;$ A. $17,6,5 \S 172$ ), e falaremos, mais adiante, de suas providências a favor dos veteranos e colonos militares (n. 390-401). E', pois, significativo o fato de o exército em pêso acompanhar o corpo de seu chefe falecido de Jericó a Herodium (G. 1, 33, 8 § 672s; A. 17, 8, 3 § 198s). E' significativa, outrossim, a importância que, nesta ocasião, se atribui às fôrças armadas, como corporação ao lado do povo, na leitura do testamento do soberano, e na proclamação de Arquelau (G. ib. $\S 666.670 ; 2,1,1 \S 3$ ) (64). Veremos, todavia, a seu tempo, que esta atividade do povo e do exército não significam sua participação pròpriamente dita nos negócios do govêrno.

358. - Pouco se fala da marinha de guerra de Herodes, como é natural. Podemos ver seu início simbólico na trireme que êle mandou construir em Rodes por ocasião de sua fuga para Roma, em 40 a. C. (nn. 137. 150). Todavia, numa época em que as galeras romanas patrulhavam eficazmente o Mediterrâneo, uma marinha particular era antes um artigo de luxo, do que uma necessidade. Estava, contudo, inteiramente dentro do caráter de Herodes ter-se dado ao luxo de possuir sua armada própria, por diminuta que fôsse, e exibí-la na primeira oportunidade. Seu pôrto era, naturalmente, Cesaréia, reconstruída a partir de 22 a. C., no local da anterior Tôrre de Estratão (A. 15, 9, $6 \S 331 ; 16,2,2 \S 21 ;$ n. 261). Com efeito, todo o litoral da Palestina não apresenta pôrto natural algum (G. $1,21,5 \S 409$; A. $15,9,6 \S 333$; Ap. $1,12 \S 60)$, e o pôrto artificial de Cesaréia, que igualava, ou mesmo superava o do Pireu (A. ib. $\S 332$; G. ib. $\S 410$ ), devia oferecer vantagens enormes aos navegantes (A. 15, 9, $6 \S 333$; G. 1, 21, $7 \S 414$ ), constituindo, ainda, uma fonte de rendas seguras para os cofres do Estado (65). Lemos que, em 14 a. C., Herodes foi juntar-se com

(64). - Em A. 17, 8, $2 \S 194.4 \S 202$ omite-se, como dissemos (nota 58) a alusão à presença do povo.

(65). - Ver F.-M. Abel, Le littoral palestinien et ses ports, Revue Btblique, N. S. 11 (1914) 556-590. Naturalmente sempre existiram pequenos portos na Palestina, que continuaram a ser usados tambem depois da construção de Cesaréia. A Epístola de Aristélas, $\S 115$, fala dos portos de Ascalão, Jafa, Gaza e Ptolemaide. Sôbre os portos de Ascalāo e Gaza - Mayumas de Ascalão e de Gaza - ver F.-M. Abel, Géographie 2, 374s; sôbre Jafa, G. 3, 9, $2 \S 414-427$, S. Cirilo de Alexandria, In Jonam 1, 3 (PG. 71, 605C) e F.-M. Abel, ib. 355s. Até à construção do pôrto de Hatfa (1929-1931) Jafa continuou sendo o porto princlpal da Palestina, mas os navios maiores atracavam ao largo, devido aos arreclfes do pôrto. Usava-se também o pórto de Antedón-Agrípias (n. 261), A. 18, 
sua armada a Marco Agripa no mar Negro, onde a guerra ameaçava eclodir (A. 16, 2, $2 \S 21-23$; nn. 244. 265) (66), e é provável que realizasse tôdas as suas viagens em seus próprios navios, que o tornavam independente dos navios particulares, e lhe facilitavam suas comunicações com Roma e outros pontos do Império (67).

359. - II. Fortalezas. - Entre os meios mais eficazes para garantir a segurança interna da Judéia e sua defesa externa, encontravam-se, certmente, as fortalezas (68). Não é, por conseguinte, de admirar, que nos dez primeiros anos do govêrno de Herodes ouçamos falar, quase exclusivamente, da construção ou reconstrução de praças fortes. O fato é bem compreensível, diante da posição precária em que ainda se encontrava o rei em face de seus novos súditos, e diante do papel que lhe cabia como rei aliado, na defesa das fronteiras do Império (69). Contudo, não nos interessam aqui as cidades mais ou menos fortificadas, como o eram, em geral, as cidades antigas (70), ou aquelas que se fortificavam às pressas para resistir às incursões inimigas (71), e tampouco nos ocupamos com os fortins que se mencionam uma ou outra vez na história de Herodes, e

6, $3 \S 158$ s. Recentemente explorou-se o pôrto de Azoto -tell Mor, ver M. Dothan, The Ancient Harbour of Ashdod, Christian News from Israel 11 (1960) 16-19.

(66). - A frota mencionada deve ter sido criação do próprio Herodes, W. Otto 58. Neste caso pode afirmar-se, com A. H. M. Jones 65, que êle devia sentir-se orgulhoso dela, exibindo-a na primeira oportunidade. $O$ único indício para julgar do tamanho da esquadra de Herodes é o plural navios, empregado em A. 16, 2, $2 \$ 17$ e 21. Depois da viagem ao Ponto a frota recolhe-se novamente a Cesaréia, ib. $5 \$ 62$, o que prova que esta cidade era o pôrto próprio da frota. Sôbre a marinha romana desde Pompeu, e o papel importante de Marco Agripa no desenvolvimento da mesma, ver J. Kromayer-G. Veith, ib. 612-615. José nos informa que no tempo dêle havia no mar Negro quarenta navios romanos com três mil tripulantes, G. $2,16,4 \S 367$.

(67). - Falaremos das viagens de Herodes, das de seu filho Antípater, etc., ao tratarmos da política exterior do rei e ao darmos um esquema de suas atividades durante o periodo do áuge de seu poder. Ver também o $n$. 264s.

(68). - Ver E. Bikerman 53-55 sôbre as fortalezas dos selêucidas em geral, e 1 Mac. 9, 50-53; 10́, 12-14 sôbre suas fortalezas na Judéia.

(69). - W. Otto 76. Ver E. Bikerman 55, sôbre a importância das fortalezas dos selêucidas para a defesa interna externa do reino.

(70). - Ver, por exemplo, Séforis da Galiléia, A. 14, 15, $4 \S 414 \mathrm{~s}$; G. 1, 16, 2 $\S$ 304; n. 155; Samaria-Sebasté e Cesaréia n. 391, e, em geral, M. Burrows, What Mean These stones, New York 1960, 136-156; $R$. de Vaux, Les institutions de l'Ancien Testament II, Parts 1960, 31-47 (Villes fortes et guerre de siège).

(71). - Ver, durante a invasão de Herodes, as cidades da Galiléla, A. 14, 12, 1 \$ 298. $15,4 \S 413.11 \S 453 ;$ G. $1,16,1 \S 303.17,3 \S 330 ; n .159$. 
que depois desaparecem da história (72). Interessam-nos, sim, as fortalezas pròpriamente ditas, construídas como tais, guarnecidas exclusivamente por soldados, e que, devido à sua importância e sua posição estratégica, ocupavam uma posição-chave no reino. Devido a êste seu caráter continuarão a aparecer no decurso da história, e determinam em grande parte a sorte das guerras, podendo transformá-las em guerras de posição, e prolongar, por conseguinte, sua duração (73).

360 . - Podemos dizer, desde já, que as grandes fortalezas de Herodes são quase tôdas reconstruções de fortalezas dos hasmoneus, o que nos dá, ao mesmo tempo, uma idéia do senso estratégico dêstes, ou, então, de seus predecessores (74). Note-se, outrossim, que as fortalezas dos hasmoneus, excetuando a capital, eram tôdas fortalezas erigidas perto das fronteiras leste e sul do reino, e que elas deviam servir de refúgios aos chefes do Estado, quando êste se visse invadido por outros lados, como se afirma expressamente de Masada (G. 4, 7, 2 § 399), além de servir de arsenais de guerra e de depósitos para os tesouros da corôa (n. 376). De resto, as montanhas da Judéia e seus defensores deviam bastar para conter os inimigos, que viessem do norte ou do oeste (75). Não se trata, todavia, de traçar aqui a história de tôdas as fortalezas dos macabeus e hasmoneus. das quais algumas. aliás. desapareceram completmente da história posterior (76), mas apenas daquelas que

(72). - Mencionamos, por exemplo, Oresa e Guitá na Iduméia, nn. 133. 152. 156. 164. 188. Conforme A. 13, 16, $5 \S 427$ Aristóbulo II, ainda em vida de sua mãe, Alexandra Salomé, conseguira apoderar-se de vinte e duas fortalezas, não identificadas.

(73). - E. Bikerman 55. Os assédios de Tiro e Gaza retardaram a marcha de Alexandre Magno sôbre o Egito por sete, respectivamente dois meses (n. 1). Ver E. Bikerman, ib.: La guerre par laquelle Antiochos III enleva à Ptolomée V la Coelésyrie dura trois ans environs (du printemps de 202 à l'été 199), dont un an et demi au moins fut rempli par les sièges de Gaza et de Sidon. - A resistência de Masada deu a Herodes o tempo necessário para sua viagem a Roma e para ajuntar um exército em Ptolemaide, nn. 151. 154s.

(74). - Conforme St. Perowne 107s a cadeia de fortalezas hasmonéias no vale do Jordāo (n. 379), pode datar de Ptolomeu I, interessado em provenir um ataque dos sirios pelo norte. Certamente a vitória de Antíoco III em Paneion em 198 a. C. (n. 4) fêz com que elas näo chegassem a participar na luta final pela posse da Palestina.

(75). - Ver sôbre o desfiladeiro de Betorón o n. $303^{42}$, e sôbre a designação dos judeus como povo sentado na montanha o n. 30340. Ver também 1 Mac. 10,70 s as palavras do general Apolônio a Jonatã Macabeu e a paráfrase das mesmas em A. $13,4,3 \S 89$.

(76). - Assim Betsur, a 29 quilômetros a so de Jerusalém, 1 Mac. 4, 29, 61; 6, 7, etc.; F.-M. Abel, Géographie 2, 283, etc.; Dok, sôbre o djebel Qarantal, 1 Mac. 16,$15 ;$ n. 304:5; Guitá e Oresa, mencionadas na nota 72 . Estrabão, Geographica 16, 2, 40 (p. 763) menciona ainda as fortalezas de Lysias, Tauros e Threx. A primeira não se conhece; sôbre as duas outras ver o n. 374. Não se conhecem igualmente as vinte e duas for. talezas mencionadas em $A .13,16,5 \S 427$ (ver nota 72). 
passaram às mãos de Herodes, e que desempenharam papel de importância no período sucessivo.

361. - Entre elas salienta-se, de modo todo especial, o baluarte, construído, já em tempos de Neemias, ao lado norte do templo (77). Na época dos macabeus designavam-se como ăкра (A. 12, 3, 3 § 133. 138), ou а́кро́тодıs (2 Mac. 4, 12; A. 14, $1,2 \S 5 ; 15,11,4 \S 403$ ), que se deve distinguir, contudo, da äкра da guarnição síria, construída por Antíoco IV, situada provàvelmente na colina de Ofel, ao sul da esplanada do templo, e tomada por Simão Macabeu (78). Parece que João Hircano a reconstruiu (A. 18, 4, $3 \$ 91$ ), e seus sucessores se empenharam em mantê-la e aumentá-la (A. 15, 11, 4 § 403). A fortaleza passou posteriormente a chamar-se de $\beta \hat{a} \rho \iota s$ (A. 15, $11,4 \S 403$; G. $1,3,3 \S 75.5,4 \S 118$ ). forma grecizada do hebraico birah (79). Servia ela de residência aos hasmoneus (G.

(77). - Ver Neh 2, 8; 7, 2. Descreve-se na Epístola de Aristéias, $\$$ 100-104. Sôbre sua história anterior a Herodes ver L. H. Vincent-A. H. Steve, Jérusalem (n. 82) 1, 193. 215.

(78). - Ver o n. $302^{34}$ e 1 Mac. $1,33.36 ; 2,31 ; 4,41 ; 6,18 ; 7,32 ; 14,36$. Simão Macabeu a tomou, ib. 13, 49-52. Ver também G. 5, 4, 1 § $137.6,1$ \$ 253; A. $12,5,4 \S 252.7,6 \S 318,9,3 \S 362-365 ; 13,6,6 \S 208.7 \S 215$; H. St. Thackeray 7,$128 ; H$. Bévenot, Die beiden Makkabäerbücher, Bonn 1931, 52. 145; G. Dalman, Jerusalem und sein Gelände, Gütersloh 1930, 134s; M. Burrosw, ib. 151; C. Watzinger, Denkmäler (n. 82) 2, 21. Outros localizam a fortaleza dos sírios no local da posterior residência dos hasmoneus no centro da cidade (n. 131): L. H. Vincent, Acra, Revue Biblique 43 (1934) 206-236; F.-M. Abel, Maccabées 16s; L. H. VincentA. M. Steve, Jérusalem (n. 82) 1, 175-192. Debaixo de Antíoco IV a guarnição da acra estava composta de cipriotas e mísios, 2 Mac. 4, 29; 5, 24; F.-M. Abel, Maccabées 339s, enquanto E. Bikerman 54, por engano, lê cretenses em lugar de cipriotas em 2 Mac. 4, 29. O dia da retirada das tropas sírias pode considerar-se como o dia da plena independência dos judeus, e como tal o dia passou a considerar-se como dia de festa, 1 Mac. 13, 51, E. Bikerman, ib. O livrinho, chamado Rolo dos Jejuns, $\S 5$, dá o dia 23 de Iyyar, 1 Mac. 13, 51 o dia 23 do segundo mês do ano 171 da éra selêucida - maio de 142 a. C. (E. Schürer 1, 262), conforme outros de 141 a. C. (G. Ricciotti 321; F.-M. Abel, Maccabées 246), como o dia em que a guarnição síria deixou a acra. Ver P. Riessler, Altjüdisches Schrifttum ausserhalb der Bibel, Augsburg 1928, 346; E. Schürer 1, 262. o Rolo dos Jejuns contém uma lista dos dias festivos, em que não é permitido jejuar; E. Schürer, ib. 163.

(79). - Assim já os Setenta traduzem birah por baris em 1 Esd. 6, 22, por bira em 2 Esd. 12, 7 (= Neh 7,2), e baris pelo aramaico birtha em 2 Esd. 6, 2. Birtha é o nome que os judeus de Elefantina e Assuân (n. 298) dão às suas cidades, A. Cowley, Aramaic Papyri of the Fifth Century B. C., Oxford 1923, 279s (índice). Baris é igualmente o nome que José dá à fortaleza da família dos Tobíadas, construída nos tempos dos ptolomeus em Tiro = Araq el-Amir, na Transjordânia, A. 12, 4, 11 \$ 230; C. Watzinger, Denkmäler (n. 82) 2, 13s, etc. Nos papiros gregos, chamados de Zenón, transcreve-se a forma aramaica Birtha da Amonítide $=$ distrito de Filadélfia-Ammân, ver H. L. Vincent, La Palestine dans les papyrus ptolémaiques de Gerza, Revue Biblique 29 (1920) 182. 189; A. S. Hunt-C. C. Edgar, Select Papyri I (Loeb Classical Library), LondonCambridge, Mass. 1952, 97, n. 31; G. Ricciotti 251-254. 
$1,3,3 \S 75 ;$ A. $18,4,3 \S 91 ; 13,11,2 \S 307$ ), de refúgio (G. 1 , $6,1 \S 121$; A. $14,1,2 \S 5$ ), de prisão (A. 13, 16, 5 § 426; 14, 1, 2 $\S 5$; G. $1,5,4 \S 118$ ), e, ainda, de depósito para as vestes pontificais, desde os tempos de João Hircano (A. 15, 11, 4 \& 463; $18,4,3 \S 90 \mathrm{~s})(80)$. Não lhe faltava o subterrâneo clássico, que se chamava Tôrre de Estratão, exatamente como a cidade marítima, cujo nome fôra mudado por Herodes em Cesaréia (A. $13,11,2 \S 307-313$; G. $1,3,3 \S 75-5 \S 80$ ) (81). Quando os muros de Jerusalém foram mandados desmantelar por Pompeu (n. 14), provàvelmente foi também desmantelada a $\beta \hat{a} p ı s$. Quando César, por sua vez, autorizou a reconstrução dos muros da cidade (n. 19), é provável que Antípater reconstruisse igualmente a acrópole, tão necessária para a dominação completa da capital e do país (82).

362. - Das outras fortalezas dos hasmoneus só nos interessam aqui as de Alexandrium, de Hircânia, de Maqueros e de Masada. A fortaleza de Alexandrium, situada no pico de Sartabé na planície jordânica (n. 160), e primeiramente construída por Alexandre Janeu (103-76 a. C.), serviu de refúgio a Aristóbulo II na sua resistência a Pompeu, sendo forçado a cedê-la com as outras fortalezas em seu poder (G. 1, 6, 5 § 134137; A. 14, 3, 4 § 49-52). Provàvelmente a praça forte foi desmantelada nesta ocasião, juntamente com as de Hircânia e de Maqueros, a primeira fundada por João Hircano, a segunda por Alexandre Janeu (G. 7, 6, 2 § 171), porque pouco depois vemos que são novamente fortificadas por Alexandre, filho de Aristóbulo II, por ocasião de seu primeiro levante, após sua fuga no caminho para Roma (n. 15; G. 1, 8, 2 § 161; A. 14, 5, 2 § 83). Entregues a Gabínio, as três praças fortes foram, ainda uma vez, desmanteladas (G. 1, 8, 5 § 167s: 7, 6, 2 § 171; A. 14, 5, 4 $\S 89 \mathrm{~s})$. Alexandrium e Maqueros, reconstruídas mais uma vez, foram os centros principais da resistência de Aristóbulo II, em 56 a. C., ano em que conseguiu evadir-se de Roma (n. 15; G. $1,8,6 \S 171-173$; A. $14,6,1 \S 92$. 94-96). Também outras fortalezas cairam em suas mãos, porque Gabínio conseguiu do Senado a libertação dos filhos daquele rei, mediante a entrega das

(80). - Ver A. 18, 4, $3 \S 90-95 ; 20,1,1 \S 7-2 \S 14$, e U. Holzmeister 109, sôbre a história posterior do ornato pontifical.

(81). - Sôbre a morte de Antígono, irmão de Aristóbulo I, neste subterráneo, ver G. $1,3,2 \S 72-5 \S 80 ; A, 13,11,3 \S 303-2 \S 313$.

(82). - Em A. 14, 4, $2 \& 61$ mencionam-se grandes torres no lado norte da c1dade, sua parte mais fraca (n. 166), o que pode entender-se da baris, que fazia parte das muralhas da cidade, H. St. J. Thackeray 7, 479. Já Alexandre, filho de Aristobulo II, tentou reconstruir os muros de Jerusalém, senđo impedido pelos romanos, G. 1, 8, $2 \S 160 ; A .14,5,1 \S 82 s$. 
mesmas por parte de sua mulher (G. 1, 8, 5 § $168.5 \S 174 ; \mathbf{A}$. $14,5,4 \S 90.6,1 \S 97$; n. 117). Na segunda revolta de Alexandre, filho do mesmo Aristóbulo (n. 15. 117), não se menciona fortaleza alguma (G. 1, 8, 7 § 176s; A. 14, 6, 2 § 100-3 § 102).

363. - E' interessante notar, que em tôda esta época não se menciona a fortaleza de Masada, castellum in rupe, como a define Plínio-o-Velho (83), fundada por Jonatã Macabeu (G. $4,7,2 \S 399 ; 7,8,3 \S 285)$, já então considerada a mais forte de tôdas (G. 1, 12, $1 \S 237$; A. 14, 11, 7 § 296) (84). E' possível que se encontrasse entre as praças fortes entregues pela mulher de Aristóbulo II, mas nada ouvimos sôbre sua desmantelação. A razão disto é óbvia. Com efeito, depois das conquistas de Alexandre Janeu na Transjordânia (A. 13, 15, 4 § $395-397 ; 14,1,4 \S 18$ ), as fortalezas de Alexandrium e Hircânia, aquém do Jordão, e a de Maqueros no Além-Jordão, já não podiam considerar-se como destinadas à defesa das fronteiras, mas encontravam-se, desde então, no coração do país. Ora, uma vez integrada a Palestina tôda no Império por Pompeu, e concedida a autonomia às cidades da Decápole (nn. 14. 286), podia confiar-se a estas a defesa das fronteiras para além do Jordão. Diminuira, desta forma, de muito a importância das fortalezas citadas, que, além disto, haviam desempenhado um papel importante nos diversos levantes mencionados. Foi precisamente para evitar que servissem de bases de operações em novas revoltas, que Gabínio mandara desmantelá-las, como se afirma expressamente (G. 1, 8, 5 § 168). 364. - Outro, porém, era o caso de Masada. Não só esta praça forte, segundo nos consta, não tinha intervindo nos levantes anteriores, mas ainda sua posição na extremidade sul do país tornava-a extremamente inapta para servir de base de operações numa revolta. Vimos, com efeito, que todos os levantes mencionados haviam começado em qualquer ponto

(83). - Naturalis Historia 5, 17, 73. A expressāo define otimamente a fortaleza, como se verá mais adiante, n. 384 . O nome de Masada vem do hebraico Metsad,i Metsuda - pico de montanha, castelo edificado numa montanha, 'roccaforte', 1 Sam. 23, 14. 19; 24, 1; Is. 33, 16, etc. Trata-se, pois, da 'roccaforte' por excelêncla, mencionada, talvez, já em 2 sam. 24, 20; 1 Par. 12, 9 como lugar de refúgio de Daví. Transcrevemos Masada do grego de José, com H. St. J. Thackeray, F.-M. Abel, G. Ricciotti, etc. Estrabão, Geographica 16, 2, 44 (p 764) diz Moasada.

(84). - Difere Plínio, tb. 5, 16, 72; Machaerus, secunda quondam arx Judaeae ab Hierosolymis. - Escrevendo depois da guerra de 66-70 d. C., que viu a destruicaao de Maqueros, fala no passado. Ou Plinio refere o que the referiram sóbre a fôrça defensiva de Maqueros no passado, ou quer dizer que era a fortaleza mais poderosa depois de Jerusalém, no tocante às fortificaçōes como tais, pois quanto à posição Masada nos parece ter sido superior a tôdas as outras fortalezas. 
central do pais, e que o próprio Herodes, uma vez libertados os seus, refugiados precisamente em Masada, quando de sua fuga para Roma, retira-se com êles para a Samaria, para dirigir, dêste ponto central, a conquista do resto de seu reino (nn. 159. 162). Por outro lado, situada no extremo sul do país, e, ainda, numa região inóspita, era Masada o lugar ideal para servir de refúgio em tempo de perigo, e era precisamente para êste fim, que havia sido escolhida por Jonatã e seus sucessores (G. 7, 8, $3 \S 285 ; 4,7,2 \S 399$ ). Serviu ela, de fato, como refúgio para a família de Herodes, em $41 / 40$ a. C. (nn. 133. 136. 151. 156), e em 30 a. C. (n. 203), e êle mesmo fortifica-la-ia mais ainda, para servir-lhe de refúgio contra os inimigos internos e externos (G. 7, 8, 4 \& 300; n. 371). Depois da guerra de 66-70 d. C., servirá a fortaleza de último refúgio e derradeiro ponto de resistência aos judeus revoltados contra Roma (G. 7, 8, 1 \& 252s. 2 \& 275-9, 2 \& 406; n. 387s).

365. - Contudo, aos olhos de Gabínio e dos romanos, não podia ser êste o fim último daquela praça forte. Se as cidades da Decápole podiam servir, a leste, de guardas avançadas e pontos de defesa contra os nabateus, cuja aliança com o Império, efetuada por Marco Emílio Escauro, legado de Pompeu (85), continuava precária (n. 284), o mesmo papel cabia a Masada na fronteira sul da Judéia, onde os nabateus haviam avançado até Bersabé-Berosaba (n. 234). Ora, é preciso considerar que a defesa das fronteiras do Império, enquanto incumbia a Herodes pela parte que lhe tocava, era a sua proteção precisamente contra êstes mesmos nabateus, habitantes do deserto e semi-nômades, cuja posição geográfica, entre o mar Vermelho e o Eufrates, e indefinida a leste, favorecia uma eventual conjunção com os partas, os inimigos figadais dos romanos (86). Vê-se, por conseguinte, que Gabínio e seus

(85). - A. H. M. Jones 56: Admitted to the friendship and alliance of the Roman people by Scaurus, the first proconsul of Syria. - José, em G. 1, 8, 1 $\$ 159$, diz que Escauro devastou as vizinhanças de Petra, e que Antipater, pal de Herodes, conseguiu que Aretas III comprasse a cessação das hostilidades pela soma de 300 talentos; em A. 14, 5, $1 \S 80$ s acrescenta que Antípater se fêz fiador de mais 300 talentos além da soma dada por Aretas, o que parece referir-se a um tributo anual. Conforme Apiano, De Bello Civili 2, 10, 71, os árabes, vizinhos dos judeus, estiveram presentes em Farsala como auxiliares de Pompeu. Destas e de outras informações (n. 194. 207) pode concluir-se para uma aliança entre Roma e os nabateus (n. 22726), afirmada no texto citado sem provas, e, ao que parece, bastante exagerada pelos escritores greco-romanos, E. Schürer $3,353 \mathrm{~s}$.

(86). - Já em 40 a. C. Malcos I negou refúgio e auxílio a Herodes, quando de sua fuga a Roma, alegando ordens dos partas, que haviam invadido a Síria e a Palestina, n. 136; A. 14, 14, 1 § 372; G. 1, 14, 1 \& 276. Conforme Cássio Dión, Historia Romana 48, 41, 5 Ventídio Basso (n. 136) exigiu 
sucessores, de forma alguma, podiam negligenciar a defesa da fronteira meridional da Judéia, sem faltar a seus deveres. Daí o motivo de Masada continuar a existir, o que se prova, ainda mais, positivamente, pelo fato dela ter caído nas mãos do irmão de Málico, assassino de Antípater (n. 115), por ocasião da revolta que se deu depois da saída de Cássio Longino da Síria (n. 116).

366. - Resumindo o exposto, podemos descrever a situação militar da Judéia, sob o govêrno de Hircano II, e no momento em que Herodes se preparava para conquistar o reino, como sendo a seguinte: a ação de Pompeu e de seu legado Gabínio havia deixado o país pràticamente desprotegido. As grandes fortalezas estavam desmanteladas, e a própria capital deixara de ser cidade fortificada (nn. 14. 360s). Sòmente a fronteira sul se achava defendida pela praça forte de Masada, e, talvez, por mais alguns fortins (87), enquanto que o resto do país estava cercado pelas cidades helenísticas autônomas, restituídas ou criadas por Pompeu (nn. 14. 286). No coração do país erguiam-se as cidades livres da Samaria, de Citópolis e de Pela, com os seus respectivos territórios, que separavam a Judéia pròpriamente dita e a Peréia da província da Galiléia (n. 287).

367. -- A gratidão de Júlio César permitiu a reconstrução dos muros da capital (n. 19), e com êles, provàvelmente, também a da $\beta$ âpıs dos hasmoneus. E' talvez neste local que devem procurar-se as tropas rebeldes de Helix ou Felix, enquanto o irmão de Málico se apoderava de várias praças fortes da Judéia, inclusive da de Masada, retomadas, logo em seguida, por Herodes (n. 116). Este fato, contudo, nos demonstra que haviam ficado intactas, ou haviam sido reconstruídas, várias praças fortes menores da Judéia, e que Masada não havia sido desmantelada. Do mesmo modo ouvimos falar, por ocasião da primeira invasão de Antígono e de Marión de Tiro, como tam-

um tributo do mesmo Malcos, por ter-se comprometido com os partas. Conforme A. 1, 12, $4 \S 220$ s e S. Jerônimo, Hebraicae Quaestiones in Genesim, Gen. 25, 13 (PL 23 [1845], 977) os nabateus habitavam do mar Vermelho ao Eufrates, o que, naturalmente, facilitava sua conjunção com os partas. Em tempos de Cláudio, Abias, rei dos árabes, organizou uma expedição até as nascentes do Tigris, para invadir o retno de Adiabene, A. 20, 4, $1 \$ 77-80$. Sabemos, ainda, que em tempos de Herodes, os nabateus haviam sabido infiltrar-se em pleno território da Decápole, ocupando a fortaleza de Raepta, entre os territórios de Pela e Gérasa, A. $16,9,2 \S 283.3 \S 288$. A fortaleza identifica-se com a posterior fortaleza árabe de Qalaat er-Rabat, perto de Adjlun, F.-M. Abel, 1, 389; cf. G. Lankester Harding, The Antiquities of Jordan, London $1959,59$.

(87). - Oresa, Guitá, etc., se ainda existiam; ver nota 72. 
bém em ocasião posterior, de várias praças fortes da Galiléia (nn. 120. 159), igualmente não especificadas, podendo, todavia, tratar-se de cidades ou aldeias fortificadas às pressas (n. 359). Masada, como se viu (n. 364), foi de extrema importância para Herodes, servindo de refúgio para sua família durante a invasão dos partas, e durante sua ausência em Roma e em Ptolemaide, onde preparava o exército invasor, para encetar a conquista do reino, e para libertar os seus (n. 159). Durante esta mesma campanha vemos que êle dá ordens a seu irmão Feroras para reconstruir a fortaleza de Alexandrium (n. 160), o que supõe que êle, desde os inícios de seu reinado, gozava de plenos poderes em matéria de defesa militar. Poucos anos depois, em 30 a. C., durante a viagem do rei para junto de Otaviano Augusto em Rodes, a praça forte serviu de prisão a Mariame e sua mãe, assim como Masada acolheu os filhos e outros parentes do rei (n. 203).

368. - Depois da conquista de Jerusalém, em 37 a. C., não terá êle tardado em iniciar a reconstrução da $\beta \hat{a}$ pıs dos hasmoneus, começada talvez já por Antípater (n. 361), e certamente terminada ainda em vida de Marco Antônio, não sòmente porque Herodes deu ao baluarte, em honra daquele seu protetor, o nome de Antônia (88), mas ainda porque José o afirma expressamente (89). Êste baluarte tremendo, a que José também dá o nome de $\pi$ úp $\gamma o s$, e Tácito o de Turris Antonia (90), situavase sôbre uma rocha de 50 côvados de altura, no ângulo noroeste do templo, e atingia a altura de 40 côvados. Das quatro tôrres que a franqueavam, três atingiam a altura de 50 côvados, enquanto a quarta, construída no ângulo sudeste, e que dominava tôda a área do templo, alcançava a altura de 70 côvados. Tomando, de um modo geral, dois côvados eqüivalentes a um metro (91), temos uma tôrre de $35 \mathrm{~m}$. de altura, e três tôrres de $25 \mathrm{~m}$. de altura, postadas, por sua vez, sôbre um fundamento de $20 \mathrm{~m}$., sustentado por um rochedo de $25 \mathrm{~m}$. de altura. O interior do baluarte era um misto de palácio e de quartel, e tinha tôdas as acomodações próprias duma cidade. Escadarias davam acesso aos pórticos do templo, e à própria área

\footnotetext{
(88). - Ver n. 188; G. 1, 21, $1 \S 401$; A. 15, 11, 4 \$ 409; W. Otto 42; A. H. M. Jones 75; St. Perowne 117.

(89). - G. 1, 5, 4 § 118; epikratêsantos Antôníou. Ver Tácito, Historiarum 5, 11: Turris Antonia, in honorem $M$. Antonil ab Herode appellata.

(90). - Tácito, tb. Em G. 5, 5, $8 \S 240$ e 242 a estrutura tôda se designa como pyrgoeidês $=0$ que se assemelha a uma tôrre, turriforme.

(91). - W. Bauer, Griechisch-deutsches Wörterbuch zu den Schriften des Neuen Testaments und der ibrigen urchristlichen Literatur, 4. ed., Berlin 1952, 1196:0,462 m.; F.-M. Abel, 1, 364; L. H. Vincent-A. M. Steve, Jérusalem (n. 82) 2,436 .
} 
do mesmo, o que facilitava às tropas aí estacionadas a intervenção rápida em caso de necessidade (92). Dêste modo, como diz José, se o templo dominava a cidade qual fortaleza, era êle, por sua vez, dominado pela Antônia, e aquêles que possuiam a esta, eram senhores de tudo (G. 5, 5, 8 § 245). Também à nova construção não faltava sua saída secreta subterrânea (n. 361), que conduzia para fora do templo, em direção à porta oriental do mesmo (A. 15, 11, $7 \S 424$ ), devendo tratar-se da chamada Porta de Ouro, a única que dava para o vale do Cedrón (93). No tempo dos procuradores romanos a Antônia servia de quartel à coorte estacionada em Jerusalém (G. 5, 5, 8 § 244) (94),

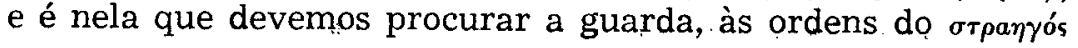

(92). - Em G. 6, 2, 5 \$ 135 narra-se que Tito, na Antônia, subiu eis tò eykátopton, para observar o andamento do ataque romano. Eykátoptos, adjetivo raro, é pròpriamente aquilo que se vê fàcilmente, o que é conspícuo; Enéias, o Tácito, Comm. Poliorcetícus 27, 2; Sátiro, Vita Euripidis, Fragmento 39, col. 2 (papiro 1176 de Oxirinco, ver H. v. Arnim, Supplementum Euripedeum [Kleine Texte 112], Bonn 1913,4). Daí pode fàcilmente passar-se para um sentido ativo, como traduzem H. St. J. Thakeray 3, 415: a spot from which he could see all below; G. Ricciotti, Flavio Giuseppe 4, 155: sul posto dell'Antonia ove si poteva veder bene all'in giù. - Diante disto cremos que se trata da tôrre mais alta do sudeste, de 35 metros de altura. - Exemplos da intervenção da guarniçāo da Antônia no templo temos na revolta contra Arquelau, G. 2, 1, 3 \$ 11; A. 17, 9, $3 \S 215$ (supondo tratar-se da guarda do templo, ver nota 95); no caso de Sabino, procurador das finanças da província da Síria, nota 99, e, sobretudo, na intervençāo dos soldados romanos no caso da prisão de São Paulo, Act. 21, 31-40; 22, 23-29. Sôbre os guardas postados nos pórticos do tempo durante as festividades judaicas, quando era maior o perigo de o entusiasmo religioso se transformar em tumulto político, ver A. $20,5,3 \S 106 \mathrm{~s}, 8,11 \S 192 ;$ G. $2,12,1 \S 224 ; 5,5,8 \S$ 244. Para ter uma idéia da extensão da fortaleza, veja-se St. Perowne 117: Within its ancient bounds now stand two convents, a school, a hospital, several streets and a number of dwellings - a catalogue which may help to indicate its huge original extent. - Este catálogo, que se baseia nas investigaçōes de L. $H$. Vincent, seus antecessores e colaboradores (ver nota seguinte), mostra, ao mesmo tempo, que o nome de tôrre se refere à forma da fortaleza, como diz José (nota 90), e não à sua extensão. A fortaleza dava antes a idéia de uma pequena cidade, G. $5,5,8 \S 241$.

(93). - A passagem citada parece ser a única em que José se refere a uma saída do templo do lado oriental, L. H. Vincent-A. M. Steve, Jérusalem (n. 82) 2, 448. Esta porta, que na Mishnah leva o nome de Porta do Palácio de Susa (Middoth 1, 3; Kelím 17, 19), não deve confundir-se com a Porta Formosa de Act. 3, 2. 10, que era uma das portas interiores do templo, ib. 468s. Sôbre a Porta de Ouro ver ib. 535-537; St. Perowne 137s; B. Meistermann, Guide de Terre Sainte, 3. ed., Paris 1935, 215s; G. Dalman, Jerusalem und sein Gelände, Gütersloh 1930, 255.

(94). - No texto citado fala-se errôneamente em tágma, nome habitual da legião romana. Ver G. $3,4,2 \S 65-67$, onde se distingue claramente entre legiōes e coortes. H. St. J. Thackeray 3, 227 e G. Ricciotti, Flavio Giuseppe 4, 60 traduzem corretamente por coorte; ver E. Schürer 2, 55. Também em A. 20,6, 1 \$ 122 tágma designa uma coorte. Ver ainda $G$. 2, 15, 6 § 332, e Act. $21,31-23,35 ; 24,7$. 22, onde o tribuno Lísias, chamado de tribuno da coorte (única, por conseguinte) em 21,31, aparece sempre como o único e supremo comandante militar da cidade, E. Schürer, ib. 
do templo (95). O pátio interno da Antônia parece ter sido

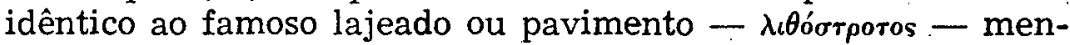
cionado nos Evangelhos (Jo. 19, 13), e, neste caso, a própria fortaleza corresponde ao pretório de Pilatos, onde foi condenado Jesus (96).

369. - Se a Antônia dominava o templo, e êste a cidade de Jerusalém, tinha a cidade alta, a parte ocidental da cidade (n. 168), ainda no dizer de José, sua fortaleza própria, o palácio de Herodes (G. 5, 5, $8 \S 245 \mathrm{~s})$. Devido, talvez, à experiência adquirida durante a invasão dos partas e de Antígono (n. 131), o rei abandonou o palácio dos hasmoneus, situado no centro da cidade (97), e construiu um novo palácio para si, no ângulo noroeste do muro antigo, de onde, mais tarde, partiria o segundo muro da cidade para o norte (98). Defendido, assim, por dois lados, pelo muro antigo, mantinha Herodes, por assim dizer ,a cidade entre dois fogos, a Antônia e o palácio novo (99). O

(95). - A. 20,6,2 $\S 131.9,3 \S 208 ;$ G. 6, 5, $3 \S 294 ; 2,17,2 \S 409$ (o primeiro sacerdote depois do pontífice); Le. 22,4 . 52; Act. 4, 1 ; $5,24.26$; 2 Mac. 3, 4: prostátês tou hierou. Ver a coorte de Arquelau em atividade no templo, em A. $17,9,3 \S 215 ;$ G. $2,1,3 \S 11$, se não se trata da infantaria real. Conforme a Epístola de Aristéias, $\$ 104$ havia quinhentos homens de guarda na acra do templo.

(96). - Sôbre a relação cronológica entre a remodelação da Antônia e a reconstrução do templo ver $W$. Otto 42 ; sôbre as escavações realizadas no local, etc., L. H. Vincent-A. M. Steve, Jérusalem (n. 82) 1, 193-216; C. Watzinger, Denkmäler ( $n$. 82) 2, 32, e, em geral, G. 1, 21, $1 \S 401$; $5,5,8 \S 238-246 ;$ A. 15, 11, $4 \$ 409$ e $7 \S 424$. - A localização do pretório de Pilatos ainda é debatida. Pronunciam-se a favor da Antônia, de onde parte igualmente a tradicional Via Dolorosa, por exemplo, G. Dalman, Jerusalem und sein Gelände Gütersloh 1930, 86; id., Orte und Wege Jesu, 3. ed., ib. 1924, 355-363; G. M. Perella, I luoghi santi, Piacenza 1936, 303-330; B. Meistermann, Guide de Terre Sainte, 3. ed., Paris 1935, 145-153; J. Pick1, Messiaskönig Jesus, München 1935, 189-197. 217232; L. H. Vincent-A. M. Steve, ib. 1, 216-221; St. Perowne 117. Sôbre as fontes antigas ver D. Baldi, Enchiridion Locorum Sanctorum, 2. ed., Jerusalém 1955, 581-592 e 593-616 (Via Crucis).

(97). - G. $2,15,1 \S 312.16,3 \S 344 ; 1,7,2 \S 143.13,2 \S 250-253 ;$ A. $14,4,2$ $\S 58$ s. 13, $3 \S 334-4 \S 338$; G. Dalman, Jerusalem (nota precedente) 79; L. H. Vincent-A. M. Steve, ib. 232-235, etc.

(98). - A tôrre de Hípicos (n. 370) marcava o infcio do muro antigo para leste, $e$ o do segundo muro para o norte, G. 5, 4, $2 \S 144$. 147; L. H. Vincent-A. M. Steve, ib. 1, 90-96.

(99). - Da tôrre de Fasael (n. 370) Sabino, procurador da província da Síria, assediado pelo povo no palácio, dá o sinal para as tropas da Antônia invadir o templo, G. $2,3,2 \S 46 \mathrm{~s} ;$ A. $17,10,2 \S 257$. Conforme A. 15,11 , 5 § 410 uma das portas ocidentais do templo, hoje Bab es-Silsileh = Porta da Cadeia e arco de Wilson, levava diretamente ao palácio real, que pode ser tanto o dos hasmoneus (n. 131), quanto o de Herodes. Uma ponte passava do templo por cima do vale de Tiropoion, então muito mais profundo (nota 144), ligando a colina do templo ao palácio dos hasmoneus e à cidade alta, G. $1,7,2 \S 143 ; A .14,4,2 \S 58$. W. Otto 80, além de citar A. 15, 11, $5 \S 410$, cita ainda ib. $7 \S 424$, onde se fala da saída secreta da Antônia em direção à porta oriental do templo (n. 368). Isto poderia dar a entender que também na primeira 
fato de êle ter dado às duas alas principais do palácio os nomes de Kaisáreion e Agríppeion (n. 261), sugere de antemão que o mesmo só foi terminado depois da batalha de Áccio, em 31 a. C., quando o rei entrou definitivamente na órbita de Augusto e de seu genro (100) .

370. - Devem distinguir-se dêste palácio e de suas fortificações as três tôrres, que o defendiam do lado norte, provàvelmente encostadas no muro antigo (G. $5,4,3$ \& 161.4 \& $473 ; 5$, $4.2 \S 142-145)$. O palácio, com efeito, defendido por muros e tôrres (G. $2,17,7 \S 431.435 ; 5,4,4 \S 177$ ), podia ser chamado de фoov́piov (G. 5, 5, 8 § 425), assim como as três tôrres formavam um só 申pov́peov (G. 2, 3, 2 § 46; A. 17, 10, $2 \S 257$ ), construído, provàvelmente, no início do reinado (101). Com efeito, além de dar largas à sua munificência e a seu orgulho por sua capital na construção suntuosa destas tôrres, descritas minuciosamente por José (A. 16, 5, $2 \S 144 ; 17,10,2 \S 257 ;$ G. $5,4,3$ $\S 163.4 \S 175)$, cedeu Herodes ainda a motivos de ordem sentimental, dando-lhes os nomes dos três entes mais queridos que já possuira: um irmão, Fasael; um amigo, Hípico; uma espôsa, Mariame, o que parece situar a construção das tôrres ainda em vida desta última (102). Além da notícia brevíssima de que

passagem se trata de um subterrâneo, o que não é o caso. Decobriuse, contudo, um subterrâneo entre o mencionado arco de Wilson, e a cidade alta, mas não se conhece sua extensão. Ver L. H. Vincent-A. M. Steve, ib. 1, 61-64 e Planche XIX. 2, 446, 552s; B. Meistermann, ib. 217s; St. Perowne 137. Se o mesmo chegasse até ao palácio de Herodes, as tropas romanas aí assediadas durante a guerra de 66-70 d. C., G. 2, 17, $7 \S 431-10 \S 456$, poder-se-iam ter evadido e juntado com as tropas da Antônia, e o mesmo poderia ter feito Sabino, a não ser que ignorassem a saída secreta. José, com efeito, não a menciona. Se fala da saída secreta da Antônla, não diz que fôsse jamais usada.

(100). - W. Otto 80: iniciado cêrca de 23 a. C., cf. A. 15, $9,3 \S 318$, depois da campanha de Elio Galo na Arábia Feliz (n. 244) e do período da sêca, etc.

(101). - W. Otto 42. 80; A. H. M. Jones 75, etc.

(102). - Com efeito, é pouco provável que Herodes tenha construído as tôrres depois da volta de seus filhos Alexandre e Aristóbulo de Roma, em 18/17 a. C. (n. 252). Nāo teria dado o nome de Mariame a uma delas, quando as discórdias entre êle e seus filhos versavam, em grande parte, em tôrno do assassinato da mãe (G. $1,23,1 \S 445,24,3 \S 480,26,2 \S$ 521. 525; A. $16,3,1 \S 67.70 .3 \S 84.4,3 \S 114$. 117). Entender-se-ia, pelo contrário, muito bem a construção da tôrre Mariame em vida daquela rainha, isto $e$, antes de 30 a. C., uma vez que depois de sua morte o rei tudo faria para esquecê-la (n. 217). Isto colocarla a construção das tôrres ainda durante o regime de Marco Antônio, e nos prímeiros anos do govêrno de Herodes, W. Otto 42. Por outro lado, José nos diz que os nomes foram dados em memória das pesosas respectivas, e o de Mariame foi dado a uma das tôrres, quando o rel havia mandado executá-1a por ciúmes, G. 5, 4, $3 \$ 162$. Contudo, os nomes de Fasael e Hípico, fá falecidos, podiam sugerir a José que também no caso de Marlame se tratava da espôsa já falecida, ou, então, escre- 
Herodes perdera a Fasael e Hípico no campo de batalha depois de luta galante (G. 5, 4, $3 \S 162$ ), Hípico nunca aparece na vida de Herodes (103). O imperador Tito mandou que se guardassem intactas as três tôrres, a fim de dar à posteridade uma idéia do que fôra a cidade, e dos obstáculos que o valor romano teve que vencer (G. $7,1,1 \S 1$ s). As tôrres, com efeito, sobreviveram às diversas transformações da cidade, e podem admirar-se seus restos no local da posterior cidadela turca, construída no século XVI, falsamente apelidada de Tôrre de Daví (104).

371. - Aos primeiros anos do reinado de Herodes deve-se igualmente a reconstrução da fortaleza de Hircânia - 'Y situada em pleno deserto de Judá (nn. 187. 304). Desmantelada por ordem de Gabínio, encontra-se ela, poucos anos depois, nas mãos de uma irmã de Antígono, das quais a recuperou Herodes, pouco antes da batalha de Accio (n. 187), o que prova que a reconstrução desta praça forte, que servirá de prisão de estado durante o govêrno de Herodes (A. 15, 10, 4 $\S 366$ ), já havia sido completada, podendo ser visitada por Marco Agripa, em 15 a. C. (nn. 187. 265). Conforme José deve-se a êste mesmo período a remodelação completa de Masada. Dizia-se, com efeito, que Herodes preparara esta fortaleza como refúgio seu contra um duplo perigo: o primeiro, por parte do povo judaico, no caso de uma revolta para restituir ao trono os hasmoneus; o segundo, o maior e o mais sério, por parte de Cleópatra, que não cessava de pedir a morte do rei e a anexação de seu reino (G. 7, 8, $4 \S 300$ s). Esta informação dataria a reconstrução de Masada ainda em vida

vendo a cem anos de distância dos fatos, não lhe ocorria o pensamento, de que Herodes não podia ter o mínimo interêsse em manter viva a lembrança da mulher estremecida, e injustamente sacrificada. Se admitimos a construção da tôrre ainda em vida de Mariame, explica-se mais fàcilmente o fato de seu nome continuar ligado à tôrre por fôrça de tradição, podendo, ainda, muitos pensar que o nome era o da sucessora da rainha assassinada, igualmente chamada Mariame, G. 1, 28, $4 \S 562$. E' o que inda hoje parece pensar St. Perowne 118.

(103). - H. St. J. Thackeray 3, 248.

(104). - Sôbre as três tôrres vejam-se L. H. Vincent-A. M. Steve, ib. 1, 222232; C. Watzinger, Denkmäler (n. 82) 2, 32s; B. Meistermann, Guide de Terre Sainte, 3. ed., París 1935, 175s. Clichês em L. H. Vincent-A. M. Steve, ib., Planches LV-LX; M. Join-Lambert, Jerusalem (n. 85) 63 . Sôbre o nome de Tôrre de Daví, ver, por exemplo, Epifânio Hagiopolita, Ad Modum Descriptionis Situs Orbis, Enarratio Syriae, Urbis Sanctae, et Sacrorum Ibi Locorum (PG 120, 261C); Itinerarium Burdigalense (do a. 333), 592 (CSEL 39, 22): Intus autem ultra murum Sion paret locus, ubi palatium habuit David; Anônimo de Placenza (cêrca de 560/570), Itinerarium 21 (ib. 173): Ascendimus in turrem David, ubi Psalterium decantavit, magma valde. Ver. D. Baldi, Enchiridion Locorum Sanctorum, 2. ed., Jerusalem 1955, 474, 484. 494. 
daquela rainha e de Marco Antônio, isto é, nos anos anteriores a 30 a. C. (n. 211). A descrição de José nos mostra aquela praça forte quase inexpugnável, e provida de um palácio, quartéis, etc. (G. 7, 8, $2 \S 275-9,2 \S 406$ ). Tomada de suprêsa - $\lambda a^{\prime} \theta_{\rho a}$ - pelos revoltosos, em 66 d. C. (G. $2,17,2 \S 408$ ), forneceu-lhes ela abundantes depósitos, não só de armas, mas ainda de mantimentos, depositados ai por Herodes quase cem anos antes (G. 7, 8, $4 \S 297$ ) (105). José atribui o fato, com muita razão, ao clima da região (106) .

372. - A última das fortalezas dos hasmoneus, que aqui nos interessam, é Maqueros - Maxaıpov̂s - a Machaerus de Plínio-o-Velho, situada no Além-Jordão, a meia altura do mar Morto, e quase nas margens dêste (107). Desmantelada por Gabínio (n. 362), parece não ter sido reconstruída por Herodes antes do advento de Otaviano Augusto. Com efeito, não a encontramos mencionada durante a primeira guerra com os nabateus, provocada por Cleópatra (n. 194-196), quando poderia ter prestado bons serviços. Sua reconstrução, além disto, teria sido contrária aos interêsses daquela rainha, empenhada numa política expansionista no Além-Jordão (n. 189) (108). Mais tarde Herodes, em vista da posição estratégica do lugar, e, sobretudo, em vista de suas próprias relações com os

(105). - Ver H. St. J. Thackeray 3, 589: If the fortress was stocked in Cleopatra's lifetime, upward of a century had clapsed, from before $31 \mathrm{~B}$. C. to A. D. 73. - Ver n. 371 os motivos da reconstrução de Masada. Láthra em geral significa: secretamente, em segrêdo. Dado, porém, o caráter normalmente inexpugnável da fortaleza, é preferível traduzir por: de surprêsa, por traição, como em Homero, Odisséia 17, 80. Ver A. Ballly, Dictionnaire Grec-Français, Paris 1950, 1164, e H. St. J. Thackeray 2, 483: by stratagem; G. Ricciotti, Flavio Giuseppe 2, 319: di sorpresa.

(106) . - G. ib. § 298: Não estaria, pois, enganado, quem pensasse ser o ar a causa desta durabilidade, que está livre de qualquer mistura terrena e impura, devido à altura daquele pico. - A causa mais exata é o clima absolutamente sêco da região. Recentemente investigou-se o nahal Tseelim, a 5 quilômetros ao norte de Masada, encontrando-se objetos do tempo da revolta de Simão bar-Kochba (132-135 d. C.), inclusive romãs, azeitonas, cevada, etc., o que plenamente confirma a José. Ver A. Biran, Archaeological Activities in Israel, 1959-1960, Christian News from Israel 11 N. 2 (1960) 16.

(107). - Plínio, Naturalis Historia 5, 16, 72. - Preferimos a grafia Maqueros, derivada do nominativo grego e de sua tradução latina em Plínio, às formas derivadas do genitivo, etc., como o francês Machéronte, o italiano Macheronte, etc. - St. Perowne 106, seduzido, provàvelmente, pelo grego máchaira = espada, traduz o nome simplesmente por The Sword. E' mais provável, diante da antígüidade da fortaleza, que o nome Makhwar, Mukawir - provenha de uma raiz semítica, como kûr, que em sentido intransitivo significa ser redondo, em sentido transitivo arredondar, o que bem descreve a forma do monte. Ver $D$. Buzy, Saint Jean-Baptiste, Paris 1922, 279². Conforme A. 18, 5, 2 \& 119 São João Batista esteve prêso em Maqueros, e aí foi executado. Ver D. Baldi, ib. 230 . 237s. 242 .

(108). - W. Otto 79 
nabateus, resolveu reconstruir a praça forte, o que êle fêz com o luxo habitual (G. 7, 6, $1 \S 164-3 \S 189 ; 1,8,2 \S 161$ ). Indiretamente, por conseguinte, a reconstrução de Maqueros deve-se à primeira guerra com os nabateus (109). Plínio-o-Velho, considerava a fortaleza a mais forte depois de Jerusalém (110).

373. - Além de reconstruir as grandes fortalezas dos hasmoneus, Herodes, já no período de esplendor de seu reinado, fundou, ainda, algumas novas, além de seu palácio de Jerusa-

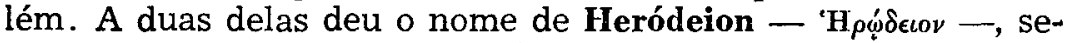
guindo o precedente dos selêucidas, que perpetuavam seus nomes por meio da construção de cidades e fortalezas (111). Mencionadas lado a lado por José (G. 1, 21, 10 § 419), só pode tratar-se de duas fortalezas distintas (112). A primeira delas, situada na fronteira árabe, isto é, além do Jordão, só se menciona uma única vez e sòmente de passagem, e ignora-se sua posição exata, que se procura, todavia, aos pés do monte Nebo (n. 314), não muito longe da ponta setentrional do mar Morto (113). A outra Heródeion, a Herodium de Plínio-o-Velho (114), construída em 23/22 a. C., no local, perto de Belém, onde Herodes outrora batera os judeus durante sua fuga para Masada (n. $133^{122}$ ), no atual Djebel Fureidis, ou monte dos Francos, foi enriquecida no melhor gôsto herodiano. Uma colina, artificialmente arredondada, sustentava a fortaleza pròpriamente dita, enquanto a seus pés se estendiam apartamentos e palácios, que formavam a cidade de Herodium (A. 15, 9, 4 \& 323325), lugar principal da toparquia dêste nome (G. $3,3,5$ § 55),

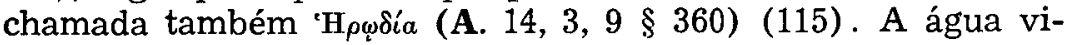

(109). - W. Otto 79 .

(110). - Naturalis Historia 5, 16, 72; ver nota 84 .

(111). - E. Bikerman 246. Conforme A. H. M. Jones, The Greek City from Alexander to Justinian, Oxford 1940,18, a dinastia hasmonéla não deixou lembranças. Os reis dos judeus preferiram ser lembrados como destruldores de cidades, e não fundadores. - E' preciso lembrar que os hasmoneus estavam empenhados numa guerra de libertação, e não estavam interessados em cidades do típo helenístico. E', pois, compreensível, que deixassem apos st fortalezas com os seus nomes, como Alexandrium, Hircânia .

(112). - U. Holzmeister 445 ; H. St. J. Thackeray 7,639 , etc.

(113). - Khirbet es-Samra, ou el-Hebbesa = prisão pequena, talvez para distin. guf-la da vizinha Maqueros $=$ prisão granđe, perto de el-Hammam (n. 315), onde se encontraram ruínas de uma fortaleza da época romana. Ver A. Mallon, Deux forteresses au pied des monts de Moab, Biblica 14 (1933) 400-405; U. Holzmeister 44; F.-M. Abel, 1, 3715; S. Perowne 106. Houve quem quisesse identificar esta Herodium com Maqueros. Ver em W. Otto 79 e A. Mallon, ib. 403.

(114). - Naturalis Historia 5, 14, 70. Sôbre a data da construção W. Otto 79 .

(115). - Em G. 3, 3, 5 § 55 Herbdeion é o nome da toparquia, e Plínto, ib., diz: Herodium, cum oppldo illustri ejusdem nominis. - Parece, pois, que êste nome era mats usado que Herodía. 
nha de longa distância, isto é, das chamadas piscinas de Salomão, perto de Belém, para suprir as necessidades do lugar (G. $1,21,10 \S 419-421$; A. $15,9,4 \S 323-325)$ (116), destinado a servir de sepultura ao próprio rei (G. $1,33,9 \S 673 ; \mathbf{A} .17,8,3$ $\S 199$ (117).

374. - Jericó, enriquecida por tôda uma cidade de palácios, a alguns quilômetros ao sul da Jericó antiga, e perto da entrada do wadi Qilt, por onde subia a estrada antiga a Jerusalém (118), recebeu como defesa uma fortaleza nova, a que Herodes deu o nome de sua mãe, Cipros - Kv́rpos - (G. 1, 21, $9 \S 417.4 \S 407 ;$ A. $16,5,2 \S 143$ ), situada provàvelmente no local da anterior fortaleza de Threx (119). Devia ela, com certeza, substituir o forte de Dok do tempo dos macabeus, situado no chamado monte da Quarentena, e que posteriormente não se menciona mais (120), tampouco quanto a fortaleza de Tauros, destruída igualmente por Pompeu, como nos informa Estrabão (121). Vemos por aí que era característico de Herodes defender suas residências com enormes baluartes e bastiões, como se viu no palácio de Jerusalém e suas três tôrres defensivas, e em Herodium (122).

375. - Serviram estas fortalezas, ao mesmo tempo, para assegurar o domínio do rei sôbre o povo judaico. Destinavamse expressamente a êste fim, como diz José, as fortificações ce Samaria-Sebasté e de Cesaréia (A. 15, 8, $5 \S 292$ ), às quais podem acrescentar-se as colônias militares de Gaba e Hésebon (r. 390). Repitamos, contudo, que a maioria das fortalezas herodianas eram apenas reconstruções das praças fortes dos hasmoneus, desmanteladas pelos romanos (n. 360), e que elas em grande parte se destinavam a conter eventuais inimigos

(116). - B. Meistermann, Guide de Terre Sainte, 3. ed., Paris 1935, 339s; F.-M. Abel, Géographie 1, 451-453; L. H. Vincent-A. M. Steve, Jérusalem (n. 82) $1,304-312$.

(117). - Ver F.-M. Abel, ib. 348; C. Watzinger, Denkmäler (n. 82) 2, 56; St. Perowne 121-123; G. Dalman, Orte und Wege Jesu (n. 85) 24.

(118). - G. Dalman, ib. 259s; C. Watzinger, ib. 53s; St. Perowne 120s; J B. Pritchard, The 1951 Campaign at Herodian Jericho, Bulletin of the American Schools of Oriental Research, N. 123 (October 1951) 8-17.

(119). - Threx é mencionada por Estrabão, Geographica 16, 2, 40 (p. 763), entre os depósitos dos tesouros dos tiranos da Juđéia, destrufdos por Pompeu; ver nota 76 e G. Dalman, ib. 259; F.-M. Abel, Géographie 2, 359.

(120). - Ver nota 76 e o n. 3044, e 1 Mac. 16, 15; G. 1, 2, 3 54-56; A. 13, 8, 1 $\S 230$. G. Dalman, ib. 106 supōe a existêncla do forte ainda em tempos de Jesus, o que não parece provável. Uma fonte aos pés do djebel Qarantal ainda hoje leva o nome de Ain Duq, próxima da qual se descobriu um antigo santuário judaico; ver $H$. Vincent, Le sanctuaire juif d'Ain Douq, Revue Biblique, N. S. 16 (1919) 532-563; B. Meistermann, ib. $279 \mathrm{~s}$.

(121). - Geographica 16, 2, 40 (p. 763; ver nota 76.

(122). - W. Otto 95 . 
externos (123), isto é, a proteger as fronteiras da Judéia, e, por isto mesmo, as do Império, como era o caso, sobretudo, com Masada e Maqueros. Serviam, enfim, de refúgios para a pessoa do monarca em tempos de perigo, como a tôrre Antônia e Masada (G. 4, 7, 2 § 399; n. 360s). Serviam, ainda, como prisões, como Hircânia, a Bastilha de Herodes (n. 371), e a tôrre Antônia, onde um dos mais ilustres prisioneiros foi São Paulo (124), e como sepulturas de muitos membros da casa real dos hasmoneus e da de Herodes (125).

376. - Não se deve esquecer, enfim, uma última finalidade das fortalezas, que era a de servirem de depósitos para os tesouros do estado, e os bens da corôa. Com efeito, é preciso lembrar, que os impostos e as taxas da época se arrecadavam e guardavam em dinheiro. As fortalezas, espalhadas pelo país, eram o lugar ideal para salvaguardar tais cabedais, não só porque ofereciam maior segurança para a sua defesa contra qualquer ataque de surprêsa de dentro e de fora do país, mas ainda porque possibilitavam a sua distribuição em parcelas, e proviam os soberanos de fundos necessários, em qualquer parte do país onde se encontrassem. Evitava-se, além disto, o perigo de tôda a reserva monetária do país cair, de uma só vez, nas mãos de inimigos internos oụ externos. José e Estrabão nos informam que já os macabeus e hasmoneus se serviam das fortalezas para êste fim, e sabemos que logo após a morte de Herodes, Sabino, procurador das finanças da província da Síria, procurou obter, por todos os meios, a entrega das fortalezas e

(123). - W. Otto 95.

(124). - Act. $21,31-40 ; 22,23-30 ; 23,10-32$. Ver também A. 13, 16, $5 \S 426 ; 14$, $1,2 \S 5 ;$ G. $1,5,4 \S 118$. $6 \S 121$ a mulher e os filhos de Arist6́bulo II, durante o seu levante contra sua mãe Alexandra Salomé e seu irmão Hircano II.

(125). - Em Alexandrium foram mandados enterrar Alexandre e Aristóbulo, filhos de Herodes e de Mariame, junto de seu avô materno Alexandre, filho de Aristóbulo II (nn. 15. 117. 122), e da maioria de seus antepassados, G. 1, 27, $6 \S 551 ;$ A. 16, 11, $7 \S 394$. Antípater, primogênito de Herodes (n. 122), foi mandado enterrar em Hircânia, G. $1,33,7 \S 664 ; A$. 17,7 , Secçāo única $\S 187$. José menciona um túmulo, respectivamente túmulos, de Herodes em Jerusalém, G. 5, 3, $2 \S 108.12,2 \S 507$. Procura-se êste túmulo no bairro de Niqefurieh, entre o King David Hotel e os muros da cidade antiga, a cêrca de 400 metros do palácio real, ver L. H. Vincent-A. M. Steve, Jérusalem (n. 82) 1, 342-346. 2, 170; C. Watzinger, Denkmälex (n. 82) 2, 68s; St. Perowne 119; Z. Vilnay, Israel Guide, 4. ed., Jerusalém 1960, 109. Neste túmulo podem ter sido enterrados Feroras, irmão de Herodes (A. 17, 3, 3 \$ 59 ; G. 1, 29, $4 \S 581$ ), Antípater, seu pai (G. 1, 11, $5 \S 288$; A. 14, 11, $4 \S 284$ ), Cipros, sua māe, Mariame, sua espôsa, etc. Entende-se que a nova dinastia dos herodianos quisesse seus túmulos próprios, e bem perto da capital. o fundador, contudo, quis seu túmulo próprio em Herodium (n. 373), enquanto seus filhos, executados por rebeldia, foram relegados a túmulos antigos e afastados. 
das contas da administração do reino (126). Alexandra Salomé guardava seus haveres mais preciosos em Hircânia, Alexandrium e Maqueros (A. 13, 16, $3 \S 41$ ). Serviram êles a seu filho Aristóbulo II para, ainda em vida de sua mãe (n. 12), recrutar um exército, e proclamar-se rei (G. $1,5,4 \S 117$; A. 13 , $16,5 \$ 427)$. Vimos igualmente que Herodes, na iminência da invasão parta, mandou levar suas posses para a Iduméia (n. 131). Refugiando-se êle, pouco depois, em Masada, é natural supor que as tivesse enviado para lá. Depois menciona-se ainda Alexandrium como depósito dos tesouros reais (A. 16, 10, 4 § 317), mas sabemos que Sabino exigiu a entrega de tôdas as fortalezas, e sabemos, ainda, que em Séforis da Galiléia os rebeldes do tempo de Arquelau puderam prover-se não só de armas, mas também de dinheiro (A. 17, 10, 5 § 271).

377. - Diante desta múltipla importância das fortalezas com relação à defesa interna e externa do regime e das finanças do reino, entende-se que seus comandantes - фpov́papxo (G.

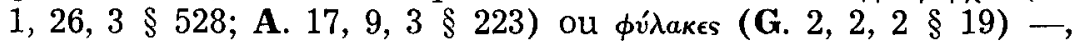
inteiramente dependentes do rei, como todos os oficiais do exército (G. $1,23,5 \S 461$ ), deviam ser, e, de fato, eram pessoas de sua absoluta confiança (127), como prova, de modo todo particular, sua atuação durante o incidente mencionado com Sabino, quando se recusaram, absolutamente, a entregar as fortalezas, e, anteriormente, durante a doença de Herodes após a execução de Mariame, quando a mãe desta, Alexandra, procurou obter que se lhe entregassem as duas fortalezas da capital (n. 217). José nos refere que os comandantes destas eram. velhos amigos do rei, e que um dêles era Aquiab, primo-irmão do mesmo (n. 87; A. 15, 7, $8 \S 250$ ). Ambos se mostraram dignos da confiança neles depositada, e a atuação posterior de Aquiab mostra que era absolutamente fiel para com a pessoa do rei (A. $17,7,1 \S 184 ;$ G. $1,33,7 \S 662$ ) e para com o regime (A. $17,10,4 \S 270.10 \S 297$; G. $2,4,1 \S 55.5,3 \S 77$ ). Sua presença no palácio de Jerusalém, onde preveniu o suicídio de Herodes durante sua última doença, sugere que fôsse o comandante do mesmo, e um daqueles que se recusaram a obedecer

(126). - Em G. 4, 7, $2 \S 399$ diz José que os reis de antanho construiram Masada como depósito para suas propriedades e refúgio para suas pessoas durante as vicissitudes das guerras. Sendo Jonatã quem primeiramente construiu esta fortaleza, G. $7,8,3 \S 285$, os rels de antanho são êle e seus sucessores. Estrabão, Geographica 16, 2, 40 (p. 763) menciona Threx e Táuros, perto de Jericó, Alexandrium, Hircânia, Maqueros e Lísias, cuja posição não se conhece (nota 76). Cita, além disto, outros depósitos situados perto de Filadélfia-Ammân e Citópolis-Beisan, que nāo podem. ser Alexandrium e Maqueros, já mencionadas.

(127). - W. Otto 56s. Ver E. Bikerman 54 sôbre os selêuciđas, e 1 Mac. 10, 37. 
às ordens de Sabino, acatando as de Arquelau (A. 17, 9, $3 \S 223$, G. $2,2,2 \S 18 \mathrm{~s})(128)$.

378. - Em ocasiões anteriores vemos os próprios irmãos de Herodes no comando, ao menos temporário, de algumas fortalezas. José defende Masada, quando da fuga de Herodes para Roma, e protege sua família (nn. 133. 151), enquanto Feroras, mais tarde, estará no comando da mesma praça forte, e encontrar-se-á incumbido da guarda dos filhos de seu irmão, quando êste se apresenta a Otaviano em Rodes (n. 203). Na mesma ocasião o tesoureiro José e o itureu Soemo se incumbem da guarda de Mariame e sua mãe Alexandra na fortaleza de Alexandrium (n. 203). Ambos são chamados de fidelíssimos ao rei desde o início (A. 15, 6, $5 \S 185.7,1 \S 205.4 \S 228$ ). Contudo, os ciúmes injustificados dêste levam à execução imediata de Soemo (A. 15, 7, $4 \S 229$; n. 215s). Um outro exemplo do poder real sôbre seus oficiais e da fidelidade dêstes é o comandante de Alexandrium, acusado de conspirar com Alexandre. filho de Herodes, para entregar a fortaleza e o dinheiro aí depositado. Submetido à tortura, nada confessa, e uma carta de Alexandre, dirigida a êle, parece ter sido forjada por Diofanto, secretário do rei, mais tarde executado por crimes da mesma natureza (G. 1, 26, $3 \S 528 \mathrm{~s}$ ) (129).

379. - Uma visão de conjunto das fortalezas da Judéia farnos-á apreciar sua distribuição estratégica, ideada pelos hasmoneus e seus predecessores, e completada por Herodes. Nos tempos dos primeiros hasmoneus encontravam-se tôdas as grandes fortalezas, fora da capital, no vale do Jordão, ou, então, perto dêle, servindo de baluartes contra uma invasão do mesmo vale pelo lado do norte e do leste, e de refúgios para os soberanos no caso de uma invasão pelo oeste. Temos assim, de norte a sul, Alexandrium, Dok, Threx e Tauros, e, ao longo do mar Morto, Masada, que defendia, ao mesmo tempo, o sul do país na Cisjordânia (n. 365). Mais para o interior, em pleno deserto de Judá, mas próxima de Jerusalém, temos a fortaleza de Hircânia (n. 371). Alexandre Janeu ajuntará Maqueros no Além-Jordão, construída para defender a leste e sul as conquistas feitas naquela região (n. 362). Falando da posição estratégica destas fortalezas mais em particular, defendia a mais

\footnotetext{
(128). - Ver também G. 6, 7, $1 \S 358$, onde se mencionam bens de particulares, depositados no palácico de Herodes durante a guerra de 66-70 d. C. Também o templo podia servir para semelhante fim, 2 Mac. 3, 10-12. 15; G. 6, 5, $2 \S 282$.

(129). - Conforme A. $16,10,4 \$ 317-319$ é o filho do comandante que confessa o crime do pai, e entrega a carta de Alexandre, o qual, contudo, acusa o mencionado Diofanto.
} 
setentrional delas, Alexandrium, a entrada do vale do Jordão contra quem viesse do norte, de Damasco ou da Baixada Grande de Esdrelón (n. 312), e, ao mesmo tempo, barrava a entrada do vale de Fara, que dá acesso à Samaria e ao centro do país (n. 304). Assim vemos que Aristóbulo II, refugiado em Alexandrium, tenta embargar o passo a Pompeu, quando êste, em Dium, não longe do Yarmuk (130), interrompe sua marcha contra os nabateus, para invadir a Judéia (n. 14; A. 14, $3,3 \S$ $47-4 \S 53$; G. $1,6,4 \S 132-5 \S 137$ ). A fortaleza de Dok (n. 374) servia de proteção a Jericó, e, talvez, de refúgio para seus habitantes, enquanto as de Threx e Tauros (n. 374) flanqueavam a entrada do wadi Qilt, barrando a estrada de Jericó a Jerusalém (n. 304) (131). Hircânia defendia o acesso à Judéia pelo lado do vale do Cedrón (n. 304), contra quem viesse da direção do mar Morto, e do sul do país. e oferecia um refúgio não muito distante da capital. Esta mesma proximidade perto de Jerusalém fêz, provàvelmente, com que a cidadela servisse de base de operações em diversos levantes (132).

380 ., - Como vimos, Herodes, com poucas exceções, conservou o sistema defensivo dos hasmoneus e o completou, tornando-o ainda mais poderoso pela reconstrução e remodelação completa das fortalezas existentes, e o acréscimo de algumas novas. Não se ouve mais falar das fortalezas de Dok e de Tauros. A primeira, destruída, quiçá, entre o tempo em que nela se deu o assassinato de Simão Macabeu (1 Mac. 16, 1122), e o govêrno de Herodes, parece, de qualquer modo, ter perdido sua importância anterior pela mudança da cidade de Jericó mais para o sul, onde a cidade nova, bem como a estrada para Jerusalém, estavam defendidas pela fortaleza de Cipros (n. 374), construída provàvelmente no local da cidacela de Threx. A Herodium transjordânica, construída, ao que parece, aos pés dos montes de Moab, a nordeste do mar Morto (n. 373), defendia o acesso do leste. e, com a colônia militar de Hésebon e a fortaleza de Maqueros integrava o sistema defensivo da Peréia (nn. 313, 315. 372. 390). Ao mesmo tempo servia ela de proteção às diversas fontes termais da região, sobretudo à vizinha tell-Hammam, a 4 quilômetros a leste da

\footnotetext{
(130). - Dium é geralmente identificada com tell es-Ashari, perto de Irbid na Transjordânia setentrional, ver n. 19558; F.-M. Abel, Géographie 2, 306s, etc. (131). - Ver os nn. 36076. 374; F.-M. Abel, 1b. 359, etc.

(132). - Menciona-se no de Alexandre, filho de Aristóbulo II (n. 362), e, mais tarde, encontra-se nas mãos de uma irmã de Antígono (n. 187). Sôbre a posição estratégica das diversas fortalezas ver algumas indicações em M. du Buit, Géographie (n. 85) 172; C. Watzinger, Denkmäler (n. 82) 2, 55s.
} 
posterior Betharampta-Lívias (133). A Herodium cisjordânica, pelo contrário, nas vizinhanças da capital e da fortaleza de Hircânia, construída no local onde o rei vencera os judeus durante sua fuga para Masada (n. 373), dá a impressão de ter sido construída, em primeiro lugar, com o fito de manter viva a lembrança da dominação do estrangeiro bem no coração do país, e de firmar mais ainda seu domínio sôbre a capital, bem como para dar largas à sua magnificência em vista de sua futura sepultura.

381. - Além da posição estratégica das fortalezas com relação ao país que deviam proteger e dominar, convém considerar a posição das mesmas entre si, calculada, evidentemente, para realçar o valor defensivo de tôdas elas tomadas em conjunto. Diante da superfície reduzida do país todo (n. 330s), vê-se, desde logo, que elas não podiam distar muito umas das outras. De fato, de Alexandrium a Cipros e Jericó, temos de 25 a 30 quilômetros, de Masada a Herodium, as fortalezas que mais longe ficavam uma da outra, temos cêrca de 40 quilômetros, enquanto Hircânia e a Herodium cisjordânica ficavam a apenas 19 quilômetros, respectivamente 11,5 quilômetros $=60$ estádios, da capital (G. 1, 21, 10 § 419; A. 15, 9, 4 \& 324) (134). Além disto, a posição relativa de tôdas estas fortalezas entre si era tal, que cada uma delas podia ser vista de uma ou mais das restantes, o que facilitava a comunicação entre elas por meio de sinais (135). Caso contrário, devia recorrer-se a postos in-

(133). - A. Mallon, ib. 402. Ver o n. 315.

(134). - F.M. Abel, Géographie 2,38 e G. 1, 13, 8 § 265; A. 14, 13, 9 § 359. De Jerusalém ao convento de Mar Saba no wadi en-Nar (n. 304) são 15 quilômetros, B. Meistermann, Guide de Terre Sainte, 3. ed., Paris 1935, 459, e de lá a Hircânia-khirbet el-Mird (n. 385), são 20 estádios, cêrca de 4 quilômetros, F.-M. Abel, ib. 2, 350. Devemos lembrar, contudo, que as fortalezas podiam contar com as cidades mais ou menos fortificadas que as ligavam entre si. Assim Engadi, nas bordas do Mar Morto (n. 304), ficava a apenas 18 quilômetros de Masada.

(135). - St. Perowne 107. Diodoro Sículo, Bibliotheca Historica 19, 97, 1 menciona os sinais luminosos usados pelos nabateus durante a noite. Sôbre os montes dos sinais luminosos ver F.-M. Abel, Géographie 1,377 e o $n$. 382. Ver nota 99 (Sabino) e G. 5, 2, 5 \& 85, onde se fala de um vigia postado sôbre os muros de Jerusalém, e que sinaliza com sua veste. No Antigo Testamento, além de estandartes e cornetas, que serviam para convocar o exército e distinguir as diversas 'bandeiras" (Is. 5, 26; 11, 10; Jer. 4, 6. 21, etc.), temos guardas postados sôbre os muros (2 Sam. 18, 24. 26s; Is. 21, $11 \mathrm{~s}$; 3 Esd. 4, 56), sinais para comunicar notí. cias (Is. 6, 1; Jer. 51, 12, etc.), sinalização por meio de colunas de fumo (Jdc. 20, 38. 40), etc. Nos famosos ôstracos de Laquish (anteriores a 588 a. C.) fala-se na sinalização entre as diversas cidades, ver ôstraco 4, linhas 9-13 em A. Vaccari, Le lettere di Lachis, Biblíca 20 (1939) 191; R. de Vaux, Les ostraca de Lachis, Revue Biblique 48 (1939) 194; M. Burrows, What Mean These stones?, New York 1960, 65. Na Transjordânia descobriram-se fortes dos edomitas e moabitas, situados de maneira que fôssem visíveis uns dos outros, M. Burrows, ib. 146. A fortaleza de Raep- 
termediários de observação, que passassem adiante as informações recebidas (136), e não se exclui o emprêgo de pomboscorreio (137). Note-se, ainda, que a visibilidade é boa na $\mathrm{Pa}$ lestina em geral (138).

382. - De Maqueros podem ver-se Masada, a Herodium cisjordânica, Cipros e Alexandrium, e, em dias claros, também as duas tôrres, que atualmente se encontram no cimo do monte das Oliveiras (139). De Alexandrium obtém-se uma vista para o sul para até além da metade do mar Morto (140), e o pico de Sartabé é mencionado expressamente na série das montanhas, por onde se transmitiam os sinais luminosos, anunciando as neomênias, etc. (141). Herodium, Maqueros e Cipros podiam comunicar-se com Jerusalém, ou diretamente com suas fortalezas, ou, então, com os postos de observação, que deviam encontrar-se ao redor da capital. Com efeito, o monte das Oliveiras $(818 \mathrm{~m}$.) é o primeiro dos montes dos sinais luminosos, comunicando diretamente com Alexandrium, e também Maqueros figura na série dos mesmos (142). Ao sul da cidade os mon-

ta, em mãos dos nabateus no tempo de Herodes (nota 86), fazia parte, depois da conquista árabe da Palestina, da cadeia de postos de sinalização por meio de sinais e pombos-correio, que permitia a transmissão de informações entre o Eufrates e o Cairo entre o nascer e o pôr do sol, G. Lankester Harding, The Antiquities of Jordan, London 1959, 59. (136). - St. Perowne 107.

(137). - St. Perowne 119. Em G. 5, 4, 4 \& 181 fala-se de pombais nos jardins do palácio de Herodes, onde se criavam pombos. H. St. J. Thackeray 3, 253 traduz: tame pigeons; G. Ricciotti, Flavio Giuseppe 4,40: colombi domestici, enquanto $\mathrm{E}$. Schürer 1,440 insiste em que peleiádes designa pombos selvagens. Na Mishnah menclonam-se duas vêzes pombos de Herodes (Shabath 24, 3; Hullin 12, 1), as únicas menções do rei na Mishnah. Herodes, por conseguinte, parece ter sido o primeiro a criar pombos selvagens presos. Em Masada igualmente se descobriram pombais, que podem ter servido para a criação de pombos-correio, Z. Vilnay, Israel Guide, 4. ed., Jerusalém 1960, 292.

(138). - St. Perowne 107.

(139). - G. Lankester Harding, The Antiquities of Jordan, London 1959, 105: It is in a most commanding position, and from it can be seen Herod's two other mountain abodes: the Herodium not far from Bethlehem, and the Alexandrium at Qarn Sartaba north of Jericho and just west of Damiah. The towers of Jerusalem are also visible on a clear day. - $O$ autor não menciona Masada (por achar-se em terras de Israel?), nem Cipros, mas não parece haver obstáculos que impeçam a comunicação direta entre Masuda e Maqueros. Sôbre Cipros ver A. Mallon, ib. 404. As duas tôrres no monte das Oliveiras, visíveis de longe em tôdas as direções, pertencem ao convento russo da Ascensāo, e ao hospital da imperatriz Augusta Vitória.

140). - F.-M. Abel, Géographie 1, 377; id., Exploration de la vallée du Jourdain, Revue Biblique, N. S. 10 (1913) 229.

(141). - F.-M. Abel, Géographie 1, 377 ver M. Rosh Ha-Shanah 2, 4; Tos. Rosh Ha-Snanah II, 2a (ed. P. Fiebig, Der Tosephtatraktat Rosh Hashshana [Kleine Texte 130], Bonn 1914, 7).

(142). - Ver nota precedente. - Se os montes ao redor de Jerusalém sāo sua proteção (Ps. 124 [125], 2), dificultam-lhe a comunicação com o resto do país, J. Felten 1, 63. St. Perowone 117 supõe que uma das razōes 
tes permitem uma visão mais ampla, e a hodierna Ramat Rahel podia servir como pôsto intermediário de comunicações. Situa-se a $819 \mathrm{~m}$. de altura, e fica a 4 quilômetros de distância de Jerusalém e de Belém respectivamente, sendo o ponto mais alto entre ambas as cidades, do qual se obtém uma vista da cidade nova de Jerusalém, e de parte da cidade antiga, onde se situava, precisamente, o palácio real (n. 369). Parece ter sido habitada também em tempos de Herodes (143) .

383. - Um último ponto a notar nas fortalezas hasmonéias e herodianas é sua posição individual em colinas íngremes, ou sôbre picos de montanhas, e sua construção sólida e forte. Efetivamente, excetuando a tôrre Antônia e o palácio real, que faziam parte da capital, já de per si situada numa posição natural de fortaleza (144), tôdas elas estavam construídas sôbre pontos avantajados, que lhes davam maior segurança, e delas faziam sentinelas naturais das regiōes circunvizinhas. Além disto, podem observar-se nelas certos pontos característicos comuns a tôdas, que sugerem tenha a sua construção obedecido a um plano único. Assim, tôdas elas, quando possível ou necessário, estavam protegidas por meio de um talude, que mais ainda dificultava o acesso direto às mesmas; estavam providas de grande número de cisternas, e, quando possível, recebiam água suplementar por meio de aquedutos, e, em tôdas elas, a acrópole pròpriamente dita, estava separada do ter-

para a mudança da residência real para a cidade alta (n. 168), era o fato de poder comunicar-se daquele ponto diretamente com Cipros, Herodium, Maqueros, etc. Faltam-nos dados precisos para calcular a altura exata das tôrres das diversas fortalezas de Jerusalém, e a altura original dos sítios onde se achavam, para julgar se alguma delas passava em altura o monte das oliveiras e os outros montes ao redor da capital. Afirma José, pelo contrário, que da tôrre de Pséfinos, de 70 côvados $=35$ metros de altura, construída em tempos de Agripa $I$, e que se procura no Qasr Djalad, no ângulo No de onde parte o muro atual da cidade para a porta de Damaso, podia ver-se a Arábia e o território judaico até ao mar, G. $5,4,3 \S 159$; ver também $5,2,2 \S 55.3,5 \S$ 133. 4, 2 \& 147; L. H. Vincent-A. M. Steve, Jérusalem (n. 82) 1, 114-129. A notícia parece supor que de nenhum outro ponto se via o mar.

(143). - H. Senès, Les foullles de Ramat Rahel, Biblica 36 (1955) 267-269; E. Vogt, Bêt-Hakkerem = Ramat Rahel, 1b. 38 (1957) 107s; Ministry of Education and Culture, Department of Antiquities, short Guide to the Excavations of Ramat Rahel, Jerusalém 1955.

(144). - M. Join-Lambert, Jerusalem, London 1958, 8; J. Felten 1, 66. Note-se que os vales do Cedrón e do Hinom, que enquadram a cidade do leste e do oeste e sul, bem ccomo o vale de Tiropoion ( $=$ dos Queijeiros, $G$. $5,4,1 \S 140)$, que divide a esplanada do templo e a cldade baixa da cíade alta (F.-M. Abel, Géographie 1, 400-402; J. Felten 1, 634), eram muitos mais profundos na antigüidade do que o são hoje. Isto explica as palavras de Tácito, Historiarum 5, 11, ao definir Jerusalém urbem arduam situ. 
reno circunvizinho ou da montanha adjacente, por meio de uma fossa natural ou artificial (145).

384. - Assim, por exemplo, a fortaleza de AlexandriumSartabé (n. 160), a 379 metros acima do nível do mar, elevavase a 28 metros acima da planície jordânica, que neste ponto se encontra a 349 metros abaixo do nível do Mediterrâneo. O acesso ao tôpo é extremamente íngreme, e o local atual da fortaleza, a acrópole, artificialmente aplainada, está separada do platô adjacente por meio de uma profunda fossa artificial. Um aqueduto para lá conduzia as águas das colinas próximas, e descobriram-se no local restos de doze cisternas (146). Cipros, fortaleza notável por sua fôrça e beleza (G. 1, 21, $9 \S 417$; $\mathbf{A}$. $16,5,2 \S 143$ ), elevava-se ao sul da entrada do wadi Qilt (n. 304), no atual tell el-Aqabé ou Beit djabr el-Tahtani, numa colina em forma de cône, de acesso difícil, situada a cêrca de 270 metros acima da planície jordânica. Várias cisternas e um canal asseguravam o sustento da guarnição, e o wadi Qilt é um dos pontos mais ricos em fontes de tôda a Judéia (147). Masada-es-Sebbe, estava situada num rochedo isolado por todos os lados, de cêrca de 300 metros de altura, a 40 metros acima do Mediterrâneo, a 440 metros acima do nível do mar Morto, e a 4 quilômetros de distância dêste último. A fortaleza encontrava-se situada numa plataforma natural de 600 metros de comprido, por $130-240 \mathrm{~m}$. de largo, cercado por uma muralha de 1.300 metros de comprimento, guarnecida por 37 tôrres, incluindo o palácio de Herodes, depósitos, quartéis, hortas e cisternas. Estas últimas, que dependiam inteiramente das chuvas ocasionais, e que sobrevivem em número de sete ao menos, salvaram a vida aos familiares de Herodes, em 40 a. C. (n. 151). Duas veredas estreitas, fáceis de defender, levavam ao cimo. A do leste, chamada significativamente de 'serpente', devido à sua tortuosidade, era extremamente perigosa; a do oeste, mais fàcilmente praticável, estava barrada a meio caminho por meio de uma tôrre imensa (148).

(145). - St. Perowne 106s. Sôbre a origem e a técnica da construçāo de cisternas ver N. Glueck, Rivers in the Desert, London 1959, 94-97; K. Galling, Reallexikon (n. 82) 536.

(146). - F.-M. Abel, Exploration dans la vallée du Jourdain, Revue Biblique, N. S. 10 (1913) 228s; St. Perowne 106.

(147). - F.-M. Abel, Géographie 2, 359; B. Meistermann, Guide de Terre Sainte; 3. ed., Paris 1935, 373; St. Perowne 120 (onde se indica a altura de 800 pés); A. Mallon, ib. 404; C. Watzinger, Denkmäler (n. 82) 2, 522; M. du Buit, Géographie (n. 85) 193.

(148). - G. 7, 8, $3 \S 280-4$ \& 303; F.-M. Abel, Géographle 2, 380; id., Une croisière autour de la mer Morte, Paris 1911, 105-131; A. Schulten e outros, Masada. Die Burg des Herodes und die römischen Lager, Leipzig 1933; C. Watzinger, Denkmäler (n. 82) 2, 54s; A. E. Mader, Masada, Lexikon für Theologie und Kirche VI, Freiburg 1. Br. 1934, 1007s; K. Galling, 1b. 363- 
385. - Hircânia igualmente estava situada sôbre uma colina íngreme em pleno deserto de Judá (nn. 304. 371). Seu nome hodierno, khirbet el-Mird, ainda reflete sua designação simplesmente como fortaleza - do aramaico marda, através do grego -, assim como se chamava Castellion um mosteiro grego construído em seu lugar (149). A Herodium cisjordânica estava situada sôbre um cone de 900 metros de circunferência em sua base, e de 300 metros em seu tôpo, o qual se eleva a 100 metros acima da planície, e a 811 metros acima do nível do mar. Ainda existem vestígios dos edifícios construídos por Herodes, e um açude de 72 por 45 metros ainda dá testemunho do que aquêle rei fêz para prover de água a cidade e a fortaleza (150). A tôrre Antônia achava-se construída sôbre um rochedo isolado de 25 metros de altura (G. 5, 5, 8 § 238), e José menciona expressamente uma fossa, que a separava do bairro setentrional de Bezeta, e um talude que ainda mais dificultava o seu acesso (ib. $\S 239.4,2 \S 149$ ). Tácito igualmente menciona seu conspicuum fastigium (151). Mencionam-se, ainda, banhos em seu interior (G. 5, 5, 8 \& 241), e a piscina de $\boldsymbol{\Sigma}_{\tau \rho o u ́} \theta_{\text {tov }}$ (ib. 11, $4 \S 467$ ). As investigações recentemente levadas a efeito no ângulo noroeste da esplanada do templo e em suas vizinhanças, fizeram com que o baluarte herodiano pudesse ser reconstruído, e se identificassem exatamente os diversos pontos mencionados por José, permitindo, por conseguinte, acompanhar com precisão os acontecimentos que se deram no local durante a guerra de 66-70 d. C. (152).

386. - Também a Herodium transjordânica, situada aos pés dos montes de Moab (n. 373), estava localizada sôbre uma

366; G. Ricciotti, Flavio Giuseppe 4, 272-304; id., La fortezza di Masada in Palestina, in: $n$ Cantierè di Hiram, Torino 1936, 157-165; Z. Vilnay, Israel Guide, 4. ed., Jerusalém 1960, 287-292; Israel Exploration Society, Masada. Survey and Excavations. 1955-1956, Jerusalém 1957.

(149). - J. T. Milik, Dix ans de découvertes dans le désert de Juda, Paris 1957, 17; F.-M. Abel, Géographie 2, 350; St. Perowne 106, e 80/81 (fotografia). - Ver, agora, o resultado de uma exploraçāo recente, realizada no local, descrito por G. R. H. Wright, The Archaeological Remains at El Mird in the Wilderness of Judaea, Biblica 42 (1960) 1-21 (com clichês e diagramas), com um apêndice de J. T. Milik, The Monastery of Castellion, ib. 21-27. O pico de El Mird está a 250 metros sôbre a regiâo adjacente, e foi artificialmente isolado das colinas do lado oeste. Existem restos de um aqueduto, de construção herodiana, de cisternas, de sepulcros da época herodiana, etc.

(150). - B. Meistermann, ib. 333s; C. Watzinger, ib. 2, 56.

(151). - Historiarum 5, 11 .

(152). - L. H. Vincent-A. M. Steve, Jérusalem (n. 82) 1, 193-216; St. Perowne 118. 122s (aqueduto e cisternas no palácio e na Antônia); M. Join-Lambert, ib. 92 (cisterna na Antônia). 
colina de cêrca de 30 metros de altura, isolada por todos os lados, mas ligada a leste à montanha próxima por uma estreita faixa de terra. Encontraram-se cinco cisternas, servidas por um canal vindo do leste. Em geral a fortaleza apresenta muitas semelhanças com a de Cipros, juntamente com a qual montava guarda à planície jordânica. Ambas tinham aproximadamente as mesmas dimensões, apresentavam o mesmo estilo, e tinham uma finalidade puramente militar (153). Maqueros, enfim, a hodierna Mukawir, estava situada num pico isolado de 730 metros de altura, a 1.225 metros sôbre o nível do mar Morto. Munida de tôrres de cêrca de 30 metros de altura, e provida abundantemente de cisternas, era extremamente difícil de tomar (G. 7, 6, 2 174-176), e vimos que Plínio-o-Velho, a julgava inferior apenas a Jerusalém (154).

387. - A solidez das fortalezas herodianas e suas posições excelentes sob o ponto de vista estratégico, foram comprovadas durante a guerra de 66-70 d. C. Destinadas originàriamente a defender o regime herodiano, e, com êle, a manter a paz romana e garantir as fronteiras do Império, tiveram as fortalezas, pelo contrário, que ser retomadas, uma por uma, pelos próprios romanos, depois de cairem nas mãos dos revoltosos, ou por ataques de surprêsa, ou por traição. No fim da guerra Tito elogia suas tropas por ter demonstrado a todos os homens, que nem o número dos inimigos, nem a resistência de suas fortalezas, a grandeza de suas cidades, nem o heroismo dos adversários puderam conter o valor romano (G. 7, 1, 2 §). Atribuia, outrossim, à providência divina o fato de os judeus terem abandonado, sem luta, as três tôrres herodianas próximas ao palácio (n. 370), que mãos humanas ou engenhos de guerra não teriam podido tomar (G. $6,9,1 \S 411.8,4 \S 400)$. Note-se que nesta altura ainda restavam por tomar duas das praças mais fortes mencionadas, Masada e Maqueros, além da Herodium cisjordânica (G. 4, 9, 9 §555; 7,6,1 § 163s. 8, $2 \S 275$ ).

(153). - A. Mallon, ib. 401-404.

(154). - Ver n. 371; A. E. Mader, Machärus, Lexikon für Theologie und Kirche VI, Freiburg 1. Br. 1934, 762; B. Meistermann, ib. 434; G. Lankester Harding, The Antiquities of Jordan, London 1959, 105; F.-M. Abel, Géographie 2, 371s; id., Lìne croisière autour de la mer Morte, Paris 1911, 31-37; D. Buzy, Saint Jean-Baptiste, Paris 1922, 276-279; G. Ricciotti, Macheronte, il luogo di Giovanni il Battista e di Salome, in: I Cantiere di Hiram, Torino 1936, 99-113; R. North, Report from Palestine, The Catholic Biblical Quarterly 22 (1960) 425: The actual site of Machaerus fortress is held to be at the nearby isolted crag called Mushnaqa. Its summit contains ruins of structures of Herod the Great. On its slope is a large Masada-style cistern, and a well-preserved stone aqueduct leads from here toward Mukawir. The crag dominates imposingly the Dead Sea and the wadi of Callirhoe (Zerqa Main) hot springs. 
De Masada diz José significativamente, que Herodes a deixou aos romanos pràticamente como último objetivo a tomar $\mathrm{em}$ suas operações finais contra os judeus (G. 7, 8, 5 §503), como, por outro lado, esta mesma fortaleza havia sido a primeira a cair nas mãos dêstes.

388. - Com efeito, foi logo no início das ohstilidades, que alguns dos nacionalistas mais entusiastas conseguiram apoderar-se, à traição, de Masada (G. 2, 17, 2 § 408; n. 371), onde encontraram armas para dez mil homens (ib. 8 § 433s; 7, 8, 4 § 299). Foi ao segundo sucessor de Tito no comando da Palestina, Flávio Silva, que coube a conquista da praça forte, o que se deu depois de longos meses de assédio (G. 7, 8, 1 \& 252s. 2 $\$$ 275-9, 2 § 406), em maio de 73 d. C., impondo, assim, fim à guerra na Palestina. A Antônia caiu nas mãos dos revoltosos depois de um assédio de dois dias apenas. A guarnição foi passada ao fio da espada, e a fortaleza incendiada (G. $2,17,7 \S 430$ ). Isto supõe que ela fôsse tomada em assalto regular, e sua queda quase imediata só se explic pela insuficiência das fôrças que a guarneciam na ocasião (G. $2,15,6 \S 332 ; n$. 368). José nos conta os pormenores dos combates tremendos que os romanos tiveram que travar para retomá-la (G. 5, 9, 2 § 356-358. 11, 4 § $466 \mathrm{~s} ; 5,6,3 \S 267 ; 6,1,3 \S 23-2,1 \S 93)$. Pouco depois da Antônia também o palácio de Herodes e suas tôrres cairam nas mãos dos revoltosos, depois de vigoroso ataque. Conseguiram êles derrubar uma das tôrres do palácio, e as tropas romanas entregaram-se por capitulação (G. 2, 17, $7 \S 431-10 \S 456$ ). Mais tarde o palácio foi novamente saqueado e incendiado (ib. 6,7 , $1 \S 358-362$ ), enquanto suas três tôrres defensivas cairam nas mãos dos romanos sem combate (G. 6, 8, 4 § 400. 9, 1 § 409; $\mathbf{n}$. 370 ).

389. - Simão bar-Giora, um dos principais chefes revolucionários, tentou, em vão, persuadir a guarnição da Herodium cisjordânica a entregar a fortaleza (G. 4,9,5 § 518s). Pouco depois, contudo, encontramo-la nas mãos dos revoltosos (ib. $10 \S$ 555), das quais a recupera Lucílio Basso, primeiro legado da Judéia depois da guerra (G. $7,6,1 \S 163)$. Isto parece ter-se dado sem grandes dificuldades, a julgar pelo laconismo de José. Cipros foi igualmente tomada pelos revoltosos, sua guarnição massacrada, e suas defesas desmanteladas (G. 2, 18, 6 $\S 484$ ), o que deixa supor que a fortaleza foi tomada de assalto. Depois não se menciona mais o seu nome. Maqueros, pelo contrário, entregou-se por capitulação da guarnição romana, que temia $o$ assalto dos judeus (G. $2,18,6 \S 485 \mathrm{~s}$ ). O mesmo 
Lucílio Basso conseguiu, por sua vez, por meio de um estratagema, que a guarnição judaica entregasse a fortaleza espontâneamente (G. 7, 6, 4 § 190-209). Nada ouvimos sôbre o destino da Herodium transjordânica, de Alexandrium e de Hircânia. A não ser supormos uma lacuna em José, pode admitir-se simplesmente que elas cairam nas mãos dos romanos sem oferecer grande resistência, e que foram destruídas no decorrer das operações militares (155). Em todo caso, compreende-se que as fortalezas, como as descrevemos, deviam desempenhar, por sua mera presença, um papel importantíssimo na dominação do povo judaico, completado neste particular, pelas cidades fortificadas e as colonias militares.

390. - III. Colônias militares. - Depois de passarmos em revista os diversos setores da ativa durante o reinado de $\mathrm{He}-$ rodes, resta-nos falar brevemente das tropas da reserva, isto é, dos veteranos e colonos militares (n. 343). Colônias militares pròpriamente ditas foram fundadas por Herodes em Gaba, aos pés do monte Carmelo, na Baixada Grande (n. 312; G. 3, 3, 1 § 36), e em Hésebon (= Hesban), a Heshbon dos amoritas e moabitas (Num. 21, 26; Dt. 1, 4; Is. 15, 4, etc.), situada entre o território da Peréia pròpriamente dita, e o de Filadélfia-Ammân (n. 315; G. $3,3,3 \S 47$; A. 15, 8, 5 § 294) (156). Gaba, provàvelmente idêntica à Gaba mencionada, nesta mesma região, por

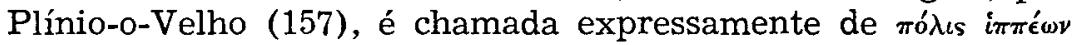
(G. $3,3,1 \S 36$ ), mas sabemos que ambas as cidades eram colônias de veteranos da cavalaria (158). Gaba não parece ter feito parte da Galiléia, mas, sim, do distrito da Baixada Grande (n. 312 ). de cuja defesa seus habitantes estavam encarregados, ou dela se encarregavam, em caso de necessidade (159). Hésebon, mais tarde, parece ter-se tornado autônoma, como as cidades da Decápole (160) .

(155), - F.-M. Abel, Exploration (ver nota 146) 234.

(156). - Sôbre a localização exata de Gaba ver E. Schürer 3, 127s; F.-M. Abel, Géographie 2, 321s.

(157). - Naturalis Historia 5, 19, 75: Promonturium Carmelum et in monte oppidum eodem nomine, quondam Acbatana dictum. Juxta Getta, Geba, rivus Pacide sive Belus. - Ver E. Schurer 3, 127; H. St. J. Thackeray 2, 586. Discorda F.-M. Abel, ib. 323.

(158). - A. $15,8,5 \$ 294 ;$ G. $3,3,1 \S 36$. Ver n. 398 a cavalarta de Ebúcio.

(159). - Ver E. Schürer 3, 127; A. H. M. Jones 78: These colonists were intended to hold Galilee in check, a function which they are recorded to have fulfilled in the Great Rebellion. - Ver mais adiante os nn. 393. 398.

(160). - Hésebon e Mádaba estavam nas mãos dos judeus no tempo de Alexan. dre Janeu, A. 13, 15, $4 \$ 397$, mas Mádaba, com mais onze vilas, fol restituída por Hircano II aos nabateus, para comprar a ajuda de Aretas III na reconquista de Jerusalém, A. 14, $1,4 \S 18$; n. 13 . Em A. 15, 8, $5 \$ 294$ fala-se da Essebonitide (= distrito de Esbous ou Hésebon) na Peréla, e Herodes não teria felto dela uma colônia militar, se năo fôs- 
391. - Também Samaria-Sebasté e Cesaréia, além de serem cidades grandemente fortificadas (A. 15, 8, 5 § 292s. 296s; G. $1,21,2 \S 403.6 \S 412$ ), eram, ainda, colônias militares. $\mathrm{Na}$ Samaria, com efeito, Herodes estabeleceu seis mil colonos, a quem se concederam lotes de terras (G. 1, 20, $2 \S 403$ ). Tratava-se de veteranos, de permeio com habitantes das vizinhanças (A. 15, 8, $5 \S 296$ ) (161). Em Cesaréia, por sua vez, vemos o veterano Tero tomar corajosamente a defesa de Alexandre - Aristóbulo, filhos de Herodes, diante da pessoa do rei (A. $16,11,4 \S 375$; G. $1,27,4 \S 544$ ), o que deixa supor que naquela cidade também se encontrassem contingentes maiores de veteranos (162). Três mil idumeus foram transplantados para a Traconítide, para conter os abusos do banditismo local (A. 16,

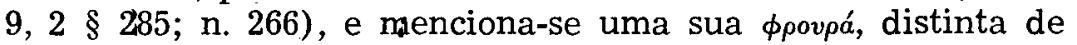
sua $\chi^{\prime}$ óa, atacada pelos traconítidas (ib. $3 \S 292$ ), o que certamente confere um sabor militar àquela colonização. Nos distúrbios que se deram depois da morte de Herodes, vemos participar dois mil veteranos da Iduméia (G. 2, 4, 1 § 55; A. 17, $10,4 \S 270$ ), pelo que se vê que também naquela toparquia havia grande número de veteranos, se não pròpriamente colonos militares, ao menos soldados que haviam voltado a seus afazeres domésticos, e podiam ser chamados às armas, em caso de necessidade (163).

392. - Todavia, o exemplo mais interessante de colonização militar, que nos fornece, ao mesmo tempo, uma indicação sôbre o fim de semelhantes emprêsas, é o dos judeus da Babilônia, estabelecidos por Herodes na Batanéia (n. 324). Estava o rei com a intenção de fundar uma vila neste território para dar cabo das incursões dos habitantes da Traconítide (n. 266; A. $15,10,2 \S 349-353 ; 16,9,1 \S 273-281$ ), quando ouviu falar de Zámaris, judeu da Babilônia, que emigrara com quinhentos seteiros montados (n. 345), e mais outros cem homens, parentes seus, para a província da Síria. Logrou Herodes convencê-lo a que se estabelecesse com os seus na Batanéia, prometendo-lhe terras e a isenção completa dos impostos. Esta colônia, cujo

\footnotetext{
se sua. Ver o n. 315 e E. Schürer 3, 129. Se, pois, José, em G. 3, 3, 3 § 47, dá como limites da Peréia Pela, Moab, a Arábia, a Essebonítide, Filadélfia e Gérasa, parece que em seu tempo Hésebon se encontrava fora dos límites da Peréía, e devia ser autônoma. Ver F.-M. Abel, Géographie 2,349 , enquanto $\mathrm{E}$. Schürer, ib., apenas conclui que a cidade năo per. tencia à Peréia em sentido administrativo.

(161). - E. Schürer 3, 125; W. Otto 57.80.

(162). - W. Otto 57. Ver o n. 355.

(163). - Em G. 2, 5, 3 $\S 76 ; A .17,10,10 \S 297$ fala-se em dez mil homens em armas na Iduméia, o que não se refere necessàriamente a veteranos apenas.
} 
centro era a vila de Bathyra (164), servia de proteção para os habitantes da Batanéia, e para os peregrinos judaicos, que se dirigiam da Babilônia para Jerusalém. Muitos judeus, de tôdas as partes, ansiosos por poder observar em paz seus costumes tradicionais, e aliciados, quiçá, pela situação tributária vantajosa (165), juntaram-se a Zámaris e os seus, e fizeram com que a Batanéia se tornasse mais povoada (A. 17, 2, 1 \& 27) (166).

393. - Semelhante deve ter sido a finalidade das outras colônias militares. Se algumas delas fortam fundadas para manter em xeque o povo judaico, como se afirma expressamente de Samaria, Cesaréia, Gaba e Hésebon (A. 15, 8, 4 \& 292-294), serviam elas, de qualquer modo, para garantir a estabilidade do regime, e para dar mais segurança ao país (ib. § 295), e, por conseguinte, maior prosperidade. Protegiam elas, com efeito, o comércio nacional e internacional, sobretudo na Peréia e nos territórios nordestinos do país, por onde passava a estrada internacional da Arábia para Damasco e a Mesopotâmia (167). Eram, além disto, quase tôdas elas colônias agrícolas, e faziam parte, desta forma, dos meios empregados por Herodes para incrementar a economia pública do reino (168). Serviam, enfim, para promover a defesa externa do país, como Hésebon (169), para promover o povoamento de distritos novos, como Sebasté e Cesaréia, e a assimilação de regiões até pouco antes alheias aos interêsses do estado judaico, como a Essebonítide, a Batanéia e a Traconítide.

394. - Tôdas elas, além disto, excetuando, naturalmente, a colônia judaico-babilônica da Batanéia, serviam para promover um dos ideais mais caros de Herodes, ou seja, a helenização progressiva do país. E' esta a finalidade que melhor explica, por exemplo, a fundação de Gaba nas vizinhanças imediatas da província da Síria, onde não parece ter havido neces-

\footnotetext{
(164). - Identificada com a hodierna Basir, perto de Sanamein, F.-M. Abel, Géographie 2, 261. Em outras passagens menciona-se a vila de Ecbátana, v. $11 \S$ 54-57, talvez idêntica com Batira, ib. 309. Outros a tomam como um dos fortes dos mesmos judeus, H. St. J. Thackeray 1, 22s. O nome reflete a origem dos judeus babilônicos. Vilas dos mesmos mencionamse em V. $11 \S 58$, e fortins em A. 17, 2, $2 \S 26$.

(165). - E. Bikerman 86. Ver A. 17, 2, $2 \S 27$.

(166). - Sôbre os motivos da fidelidade dos judeus babilônicos ver o n. 350; sôbre as mudanças no regime fiscal o n. 395 .

(167). - Ver o n. 266 e A. 17, 2, $2 \S 27$ (n. 392), onde se mencionam os peregrinos judaicos que se dirigiam da Babilônia pela Batanéia a Jerusalém.

(168). - W. Otto 90. Ver V. $11 \S 58$ sôbre gado e provisões dos judeus babilô. nicos, e A. $16,9,3 \S 292$ sôbre a chôra dos idumeus da Traconítide. Os colonos de Samaria-Sebasté receberam terras muito produtivas, G. 1, 20, $2 \S 403$.

(169). - Ver o n. $365^{\circ}$ e E. Bikerman 88 sôbre o papel das cidades fundadas perto das fronteiras da síria.
} 
sidade alguma para estabelecer uma colônia militar. Contudo, Gaba simplesmente prolongava pelo país adentro a influência das cidades gregas de Dora e Ptolemaide (n. 286). Não admira, pois, que os judeus, logo nos inícios das hostilidades contra Roma, em 66 d. C., atacassem tôdas estas cidades, nas quais não podiam deixar de ver senão instrumentos da dominação estrangeira, e da paganização progressiva do país. Mencionam-se expressamente Hésebon, Gaba, Cesaréia e Sebasté entre as cidades atacadas (G. 2, 18, $1 \S 456-460$ ). Este fato, e as contínuas desavenças entre a população judaica e grega de Cesaréia, bem como a incompatibilidade entre Agripa I e as tropas dos cesareanos e sebastenos (n. 350), as rixas entre os samaritanos helenizados e os judeus e galileus (n. 307), provam suficientemente o fato de Herodes não ter conseguido realizar o fim almejado, e que era impossível chegar-se a um compromisso entre a cultura helenística e a observância judaica, tradicional e rígida, que sempre mais se impunha, graças aos esforços persistentes dos escribas e fariseus.

395. - Aos veteranos e colonos militares concediam-se lotes de terras, fato que nos é diretamente atestado nos casos de Samaria-Sebasté e dos judeus babilônicos da Batanéia (G. 1, $21,3 \S 403 ;$ A. $15,8,5 \S 296 ; 17,2,1 \S 25.2 \S 26 ; n .391$ s), e que podemos igualmente supor nos outros casos, à semelhança dos lotes militares - $\kappa \lambda \hat{\eta} \rho \circ-$, que se costumavam dar aos veteranos nos reinos helenísticos, e, mais tarde, no Império romano (170) . O mesmo se dava, naturalmente, ao se fundarem colônias puramente civis. De ambos os tipos de colônias encontramos vestígios na literatura judaica e na epigrafia (171). Estes colonos provàvelmente não recebiam seus lotes de terra como

(170). - W. Otto 58; E. Bikerman 78-90.

(171). - Conforme 3 Esd. 4, 50. 56 Dario manda entregar terras livres de impostos aos judeus repatriados, e klêroi e soldo a todos os guardas de Jerusalém, cf A. 11, $3,8 \S 63$. Um dos Ptolomeus, indignado pela negligência no pagamento dos impostos da Judéla, ameaça lotear o país e distribuí-1o a colonos militares, A. $12,4,1 \$ 159$ e comentário de $H$. St. J. Thackeray 7, 82s. Antfoco III transferiu duas mil famillas judalcas da Mesopotâmia e Babilônia para as fortalezas e praças mais im. portantes da Lidia e Frigia (n. 397), concedendo-lhes terras para edificar suas casas e para cultivar, abrindo mão dos impostos sôbre os produtos do solo durante dez anos, A. 12, 3, $4 \S 149-153$. Ver H. St. J. Thackeray 7, 764-766 sôbre a genuinidade da narração, e E. Bikerman $84 \mathrm{~s}$ sôbre - caráter civil desta colonizzação. Antíoco IV envia Lisias para combater os judeus e povoar a terra de estrangeiros, dividindo-a em lotes, 1 Mac. 3, 32-36, cf. 1,38 e Dan. 11, 39 (LXX), E. Bikerman 85. 862. Encontrouse na Traconítide uma Inscrição de cèrca de 75-80 d. C. (reinado de Agripa II), dedicada à memória de certo Herodes, filho de Aumos, estratopedarca dos cavaleiros colonos e soldados, W. Otto 58. 166s; W. Ditenberger, Orientis Graeci Inscriptiones Selectae I, Lipsiae 1903, 636, n. 425 . 
propriedade sua, mas eram rendeiros da corôa (172), que podiam gozer de um regime tributário privilegiado, como aconteceu, temporàriamente, com os judeus babilônicos, transplantados para a Batanéia. Durante a vida de Herodes estavam inteiramente isentos de impostos. O tetrarca Filipe, senhor de terras pobres, e, por conseguinte, de poucas rendas (n. 325), começou a cobrar dêles tributos módicos e temporários, aumentados pelos dois Agripas. Os romanos, enfim, passaram a exigir dêles os impostos integrais, sem, todavia, interferir com sua administração interna (A. 17, 2, $2 \S 27 \mathrm{~s}$ ) (173). Este fato, contudo, demonstra, que êles, que de início desfrutavam de um regime excepcional, foram, pouco a pouco, submetidos ao regime comum, e assimilados aos outros colonos militares e civis, e ao povo em geral (174).

396. - Pod discutir-se, todavia, sôbre a relação exata entre a concessão de terras e o serviço militar a ser prestado pelos colonos assim beneficiados, ou, mais exatamente, sôbre o tipo de colonização militar adotado na Judéia. Podem, com efeito, distinguir-se, naquela época, dois tipos principais de colônias militares, o egípcio e o selêucida, que tinham como conseqüência dois sistemas diversos de conscrição militar. Os colonos militares egípcios estavam obrigados ao serviço militar como proprietários de lotes de terra, assim como o estavam também seus descendentes, e o serviço militar era um ônus decorrente da doação régia. O colono militar era considerado como soldado, P a clerúquia egípcia estava organizada militarmente. Os colonos de uma mesma vila podiam pertencer a diversos regimentos, ou seja, os soldados de uma mesma tropa podiam provir de localidades diferentes. Não percebiam soldo, o qual se compensava precisamente por meio da concessão de terras, e os clerucos do Egito podem considerar-se como uma espécie de exército sedentário (175).

(172). - W. Otto 57 .

(173). - Nesta pasagem José se refere ao tempo em que os romanos receberam o govêrno dêstes príncipes, o que parece referir-se aos dois Agripas. Depois da morte de Agripa I, com efeito, todo o seu reino foi administrado por procuradores romanos, até que, em 53 d. C., a anterior tetrarquia de Fillipe (que incluia a Batanéla, n. 318. 323), e a Abilene de Lisânias foram entregues a Agripa II (A. 20, 7, 1 § 138), que faleceu pouco depois de 92 d. C. Escrevendo José depols da morte dêle ( $\mathbf{V} .16$ $\S 359$ ), podia mencionar o que aconteceu quando os romanos tomaram conta dos territórios de ambos os príncipes. Ver U. Holzmeister 133. 137. 139.

(174). - W. Otto 57 .

(175). - E. Bikerman 78. 82; R. Cohen, La Grèce et l'hellénisation du monde antique, Paris 1948, 551s. Ver também, em geral, J. Lesquier, Les institutions militaires de l'kgypte sous les Lagides, Paris 1911, 162-254. 
397. - Na Síria, pelo contrário, vigorava a conscrição militar por meio do recrutamento, que se fazia por comunas, e os soldados estavam organizados em regimentos de acôrdo com seus lugares de origem. As cidades livres forneciam tropas auxiliares, e tôdas as tropas percebiam um soldo regular (176). As terras concediam-se às colônias como tais, comprometendose elas a fornecer sua quota regular de recrutas, e o próprio têrmo de.$\kappa \lambda \hat{\eta} \rho o$ s pode designar todo o território complexivo de uma colônia. Por outro lado, podiam conceder-se lotes destas mesmas terras a indivíduos, para facilitar-lhes o cumprimento do serviço militar, como já durante o domínio persa conhecemos exemplos de terras concedidas a soldados, para prover ao seu sustento e ao de suas famílias (177). Enfim, boa parte das colônias e cidades fundadas pelos selêucidas eram simples colônias civis, às quais, todavia, se confiava a tarefa de se defenderem a si mesmas, e, desta forma, garantir. a segurança interna e a defesa externa do próprio país. De fato, o têrmo $\kappa \lambda \hat{\eta} \rho \circ$ significa em geral um lote de terra concedido a um colono, sem conotar, necessàriamente, uma obrigação de ordem militar (178). A êste tipo de colonização civil pertence a transplantação de duas mil famílias judaicas da Babilônia para a Lídia e a Frígia durante o reinado de Antíoco III, e Antíoco IV estabelecerá colônias estrangeiras na própria Palestina, para quebrar a resístência dos judeus (179). Estes colonos recebiam terras confiscadas pelo govêrno aos proprietários anteriores. Estabeleciam-se em praças fortes ou cidades fortificadas, e recebiam armas e munições, sem que êste fato os tornasse soldados pròpriamente ditos. Sendo, porém, colonos estrangeiros estabelecidos em terra hostil, é evidente que sabiam, quando necessário, defender suas posses com as armas nas mãos, e serviam, desta forma, de complemento aos exércitos reais, podendo até substituí-los em tempos de paz (180). Semelhante já fôra a situação dos judeus tornados à terra de seus pais depois do exílio da Babilônia (181).

\footnotetext{
(176). - E. Blkerman 77-83. Em 1 Mac. 3, 27 Antíoco IV manda pagar adiantadamente o sôldo de um ano. Ver ib. 11, 38 a distinção entre tropas nacionais e estrangeiras, e Justino, Epitoma Historiarum Philippicarum 35, 2, 2s; A. 12, 9, $3 \S 366$. Sôbre Herodes ver o n. 357. Em M. Sanhedrin 2, 4 determina-se que o rel não ajunte demasiada prata e ouro, mas apenas o suficiente para pagar o sôldo de suas tropas.

(177). - E. Bikerman 84. 87, onde se cita o exemplo da guarnição judaica de Elefantine (n. 298).

(178). - E. Bikerman 87s.

(179). - E. Bikerman 84s, e nota 171 .

(180). - E. Bikerman 85 .

(181). - Esd. 2, 70; 7, 24; Neh. 4, 7-23. Ver nota 171.
} 
398. - Examinando, à luz destas informações o papel desempenhado pelas colônias militares fundadas por Herodes, vemos que elas representam o tipo de colonização militar síria. São vários os exemplos que confirmam esta conclusão. Temos, em primeiro lugar, a atuação dos veteranos de Gaba (n. 390) durante a guerra de 66-70 d. C. Lemos que o decurião Ebúcio estava encarregado do comando da Baixada Grande de Esdrelón (n. 312). Sabendo que José, então no comando da Galiléia (n. 45), se encontrava nas vizinhanças, foi à busca dêle, acompanhado pelos cem cavalarianos à sua disposição, mais uns duzentos soldados de infantaria, e os habitantes de Gaba, que iam como tropas auxiliares. Depois de ligeira escaramuça, Ebúcio retirou-se novamente para Gaba, onde estava estacionado (V. $24 \S 115-118)$. O texto distingue claramente entre os habitantes de Gaba e as tropas de Ebúcio. Se todos os habitantes de Gaba eram veteranos da cavalaria, ou descendentes dos mesmos, devem ver-se nas tropas de Ebúcio tropas regulares, recrutadas de modo normal entre os descendentes daqueles veteranos, ou, então, recrutados para a ocasião, enquanto os auxiliares de Gaba se juntaram a êles como voluntários, prontos para proteger suas posses e as de Agripa II contra as depredações das tropas de José (ver V. $24 \S 118 \mathrm{~s}$ ). No primeiro caso podemos comparar as coloniae militum dos romanos (182), e sobretudo o exemplo de Beirute, colônia romana desde Augusto (183), que forneceu tropas auxiliares a Varo, governador da Síria, quando de sua expedição punitiva contra a Judéia, em 4 a. C. (A. 17, 10, 9 § 287; G. 2, 5, 1 § 67). Do mesmo modo podemos ver nos sebastenos de Grato e Rufo (n. 349), e nos cesareanos a serviço de Agripa I (n. 350), não contingentes de veteranos (184), mas descendentes de veteranos, estabelecidos em Samaria-Sebasté e em Cesaréia (n. 349), obrigados ao serviço militar regular, e formando regimentos denominados de acôrdo com seus lugares de origem (185) .

399. - Temos, enfim, o caso dos judeus babilônicos estabelecidos na Batanéia (n. 392), e o dos idumeus transplanta-

\footnotetext{
(182). - E. Bikerman 81.

(183). - Conforme Estrabāo; Geographica 16, 2, 19 (p. 755s) Marco Agripa estabeleceu duas leglóes em Berito, o que deve entender-se dos veteranos das mesmas, e referir-se a cêrca de 15 a. C. Ver Plínio, Naturalis Historia 5, 20, 78: Berytus colonia; G. 7, 3, $1 \S 39 ;$ E. Schürer 1, 460-150: Colonia Julia Augusta Felix Berythus. - Belrute será mencionada mais vêzes em nossa história.

(184). - Como parece implicar W. Otto 58.

(185). - E. Schürer 3, 65; W. Otto 57 , ver o n. 397. Os cesareanos, quase sempre em companhia dos sebastenos, aparecem em G. 2, 12, $5 \S 236 ; 3,4,2$ $\S 66 ;$ A. $19,9,1 \S 356-2 \S 365 ; 20,8,7 \S 176$.
} 
dos para a Traconítide (n. 391). Sabemos que os primeiros estavam especializados no uso do arco a cavalo (n. 345), e que Iáquimos (= Joaquim), filho de Zámaris, continuou a treinar seus colonos na arte da cavalaria. Seu filho Filipe, excelente soldado, estava à testa das tropas de Agripa II, treinando-as e servindo como seu comandante. De fato, um corpo dêstes judeus babilônicos serviu de guarda aos reis (186). Contudo, não se afirma $Q$ caráter pròpriamente militar dêstes colonos. São colonos pròpriamento ditos, que se entregam à agricultura e à pecuária (V. $11 \S 58)$, e sua designação oficial era a de judeus Babilônicos de Ecbátana (V. 11 \& 54. 57). Por outro lado, estavam treinados no uso das armas, e seus chefes continuavam a treiná-los. E' por meio de sua mera presença que êles protegiam o distrito a êles confiado, ou, então, por meio de incursões contra os árabes depredadores. Governavam-se por meio de um conselho de setenta anciãos, à maneira da província da Judéia (V. $11 \S 56-58 ;$ G. $2,18,6 \S 482$ ), e estavam submetidos ao serviço militar regular, fornecendo tropas para a guarda dos reis herodianos (187), e contingentes de cavalaria em caso de guerra (G. 2, 17, 4 § 421) (188). Semelhante era a situação da colônia militar iduméia estabelecida na Traconítide. Instala-

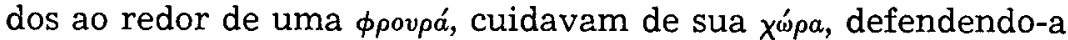
contra os ataques dos árabes (A. 16, 9, 2 § 285, $3 \S 292$ ). Já dissemos que os arqueiros da Traconítide (n. 345), que se mencionam entre as tropas fiéis à monarquia depois da morte de Herodes (G. 2, 4, $2 \S 58$ ), podiam muito bem ser descendentes daqueles idumeus (n. 349), e cavalaria da Traconítide menciona-se entre as tropas enviadas por Agripa I em socôrro dos legalistas de Jerusalém, em 66 d. C. (G. $2,17,4$ § 421).

400. - Vemos, por conseguinte, que prevalecia na Judéia de Herodes o tipo sírio de colonização militar, bem como o sistema sírio de conscrição militar, se bem que escape ao nosso conhecimento o sistema exato a que obedecia o recrutamento das tropas. Sabemos, todavia, que estas percebiam um soldo do rei (n. 357). Ora, como várias das cidades fundadas por Herodes eram colônias militares de veteranos (n. 390s), e como em tôdas elas vemos tropas regulares a serviço dos diversos reis herodianos (n. 399), podemos designá-las a tôdas, ainda que

(196). - A. 17, 2, $3 \S 29-31$. Ver ainda G. $2,18,6 \S 481-483.19,2 \S 520 ; 3,2.1$ $\S 11 ; \mathrm{V} .11 \S 47.54,35 \S 177.36 \S 183$.

(187). - E. Bikerman 86 .

(188). - Menclonam-se nesta passagem dols mil cavalarlanos da Auranítide, da Batanéla e da Traconítide, sob o comando de Dario e de Fillpe, filho de Iáquímos. Ver V. $11 \S 46-50.36 \S 179-184$ sôbre Fillpe e os judeus babllónlcos em Jerusalém. 


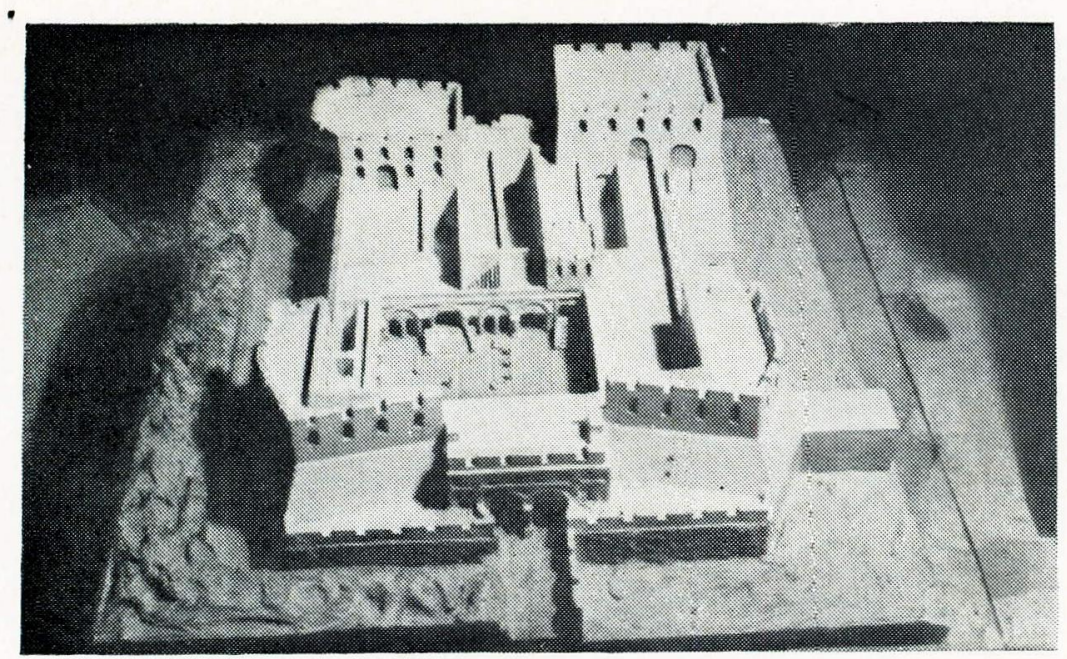

Reconstrucão da Tôrre Antônia.

(Foto Dames de Sion, Jerusalém).

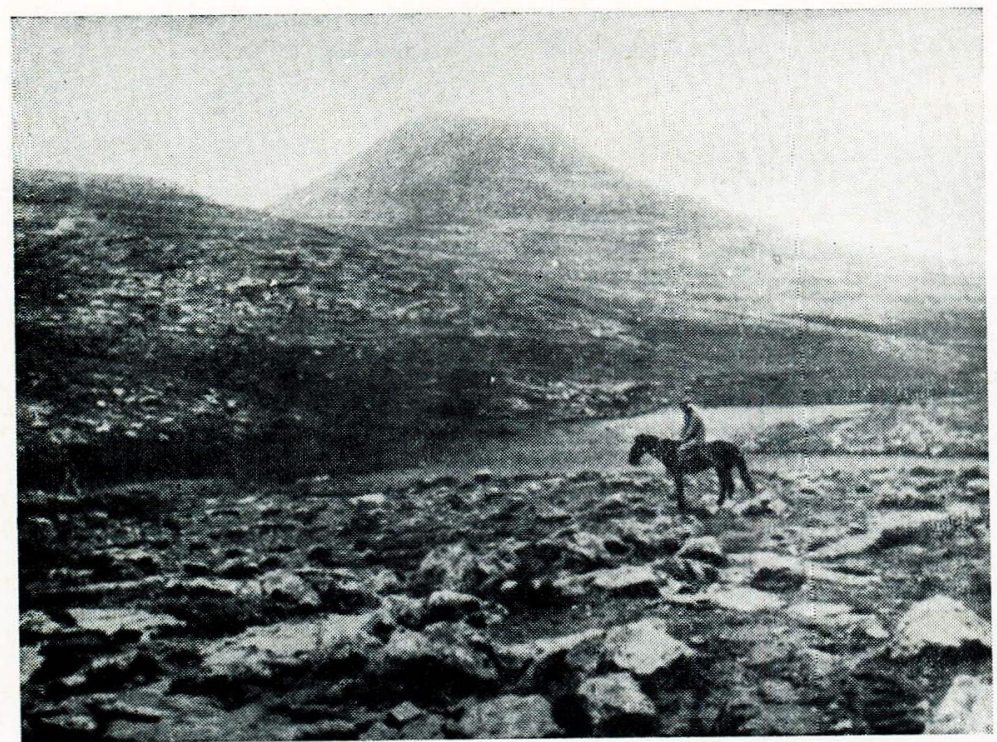

Herodium da Cisjordânia .

(M.-H. Lelong, Terre Sainte, Paris 1955, 144). 


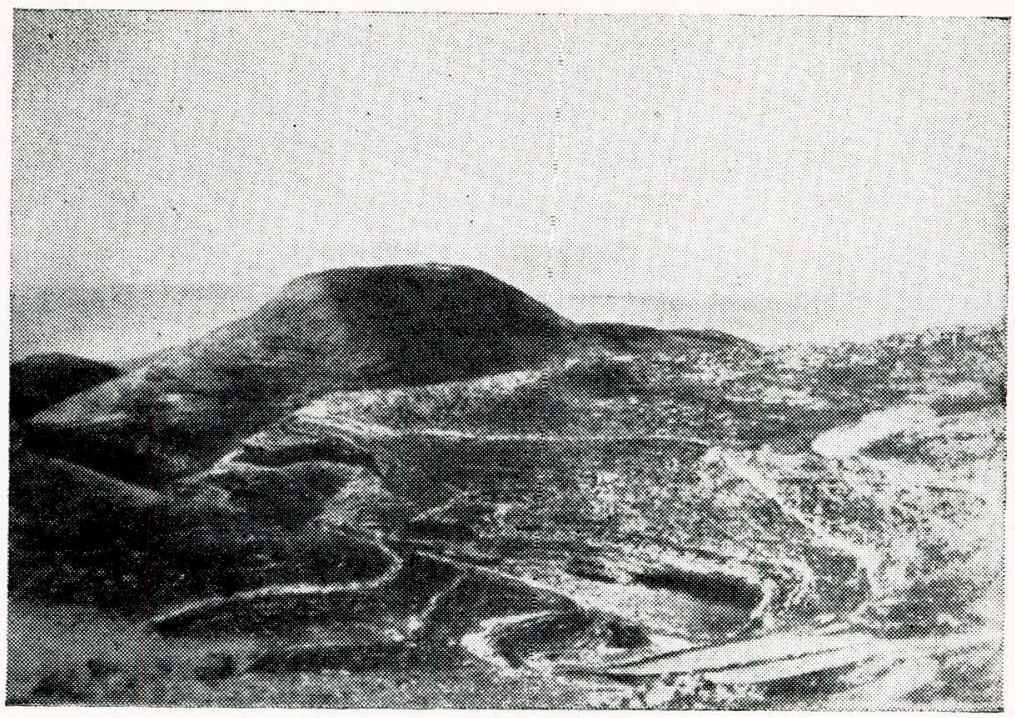

Maqueros.

(P. Lemaire-D. Baldi, Atlante Storico della Bibbia, Torino 1955, 209).

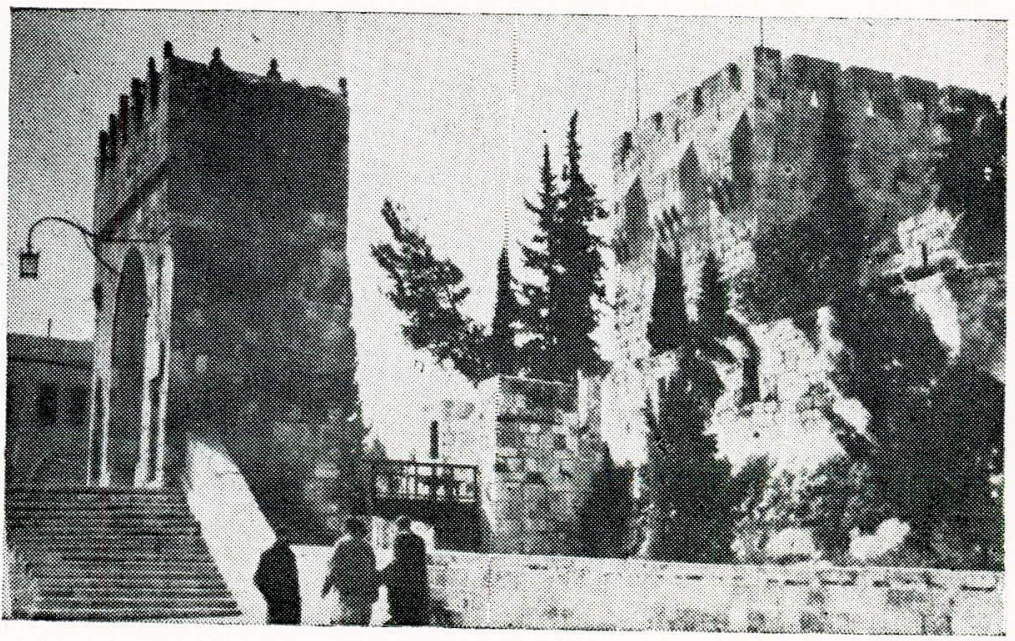

Cidadela de Jerusalém.

(Com restos do palácio e das tôrres de Herodes). 


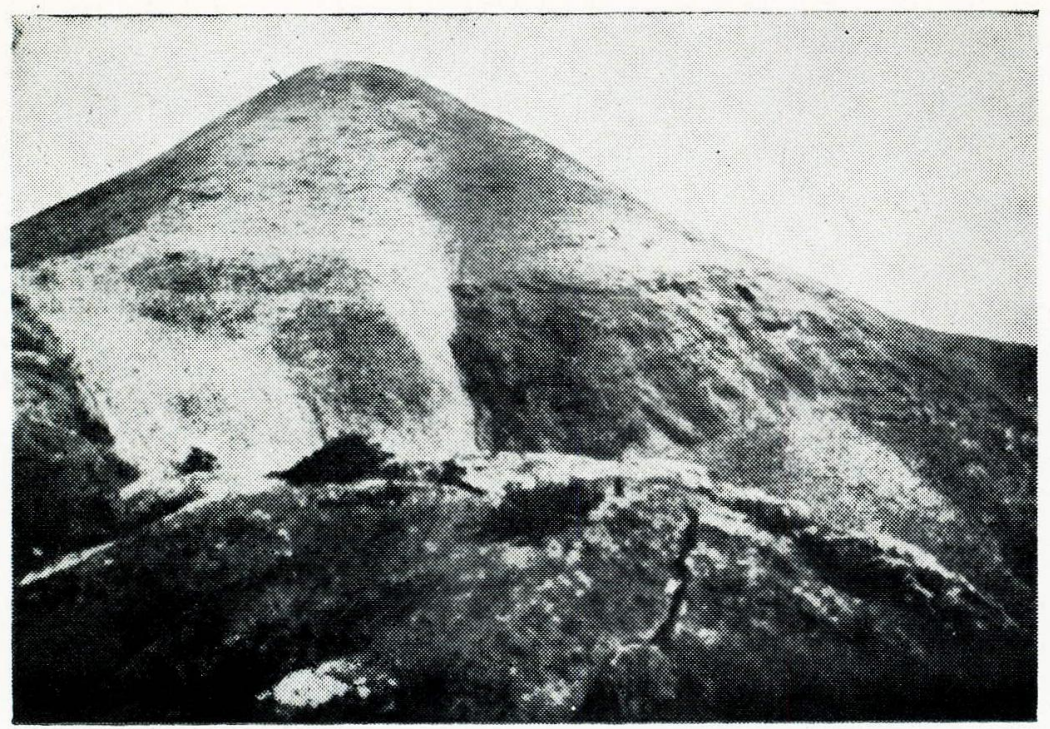

Alexandrium-Sartabé.

(Revue Biblique, N. S. 10 [1913] 218-9, Planche II, 1)

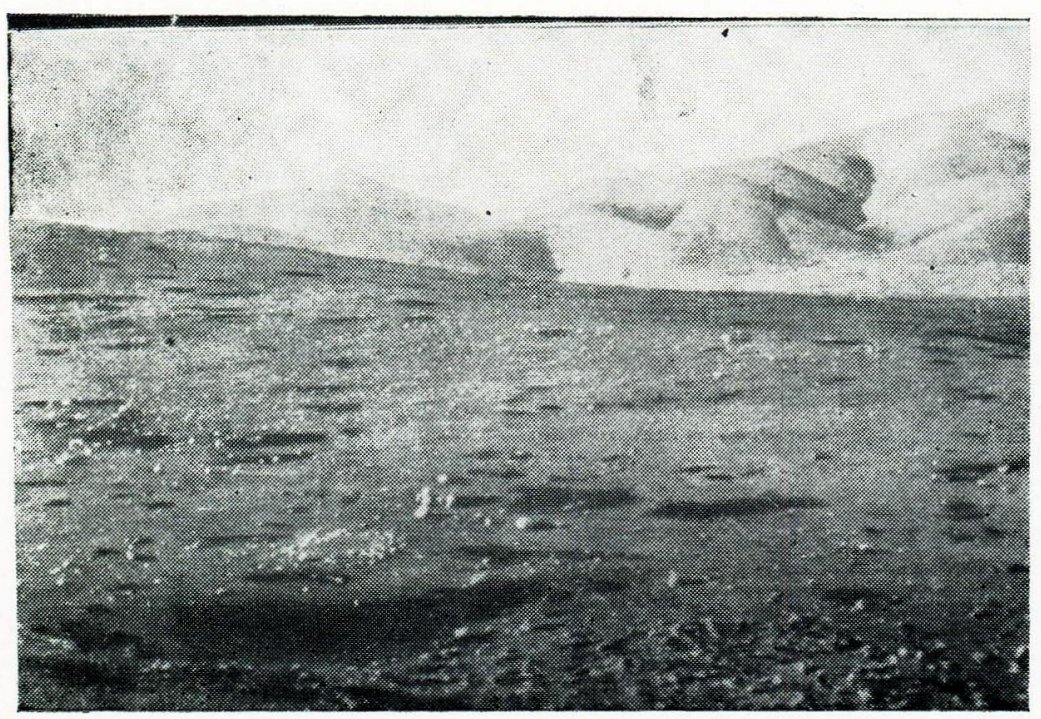

Alexandrium-Sartabé.

(Ib., Planche I, 1) 


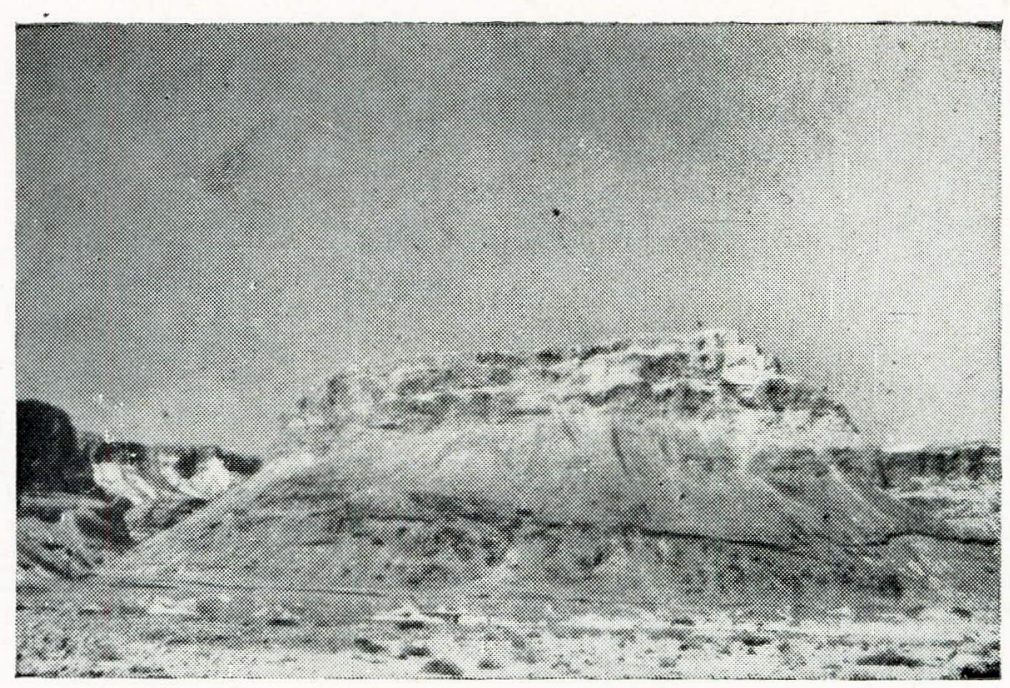

Masada.

(Foto P. Antônio Carlos Simas Magalhães).

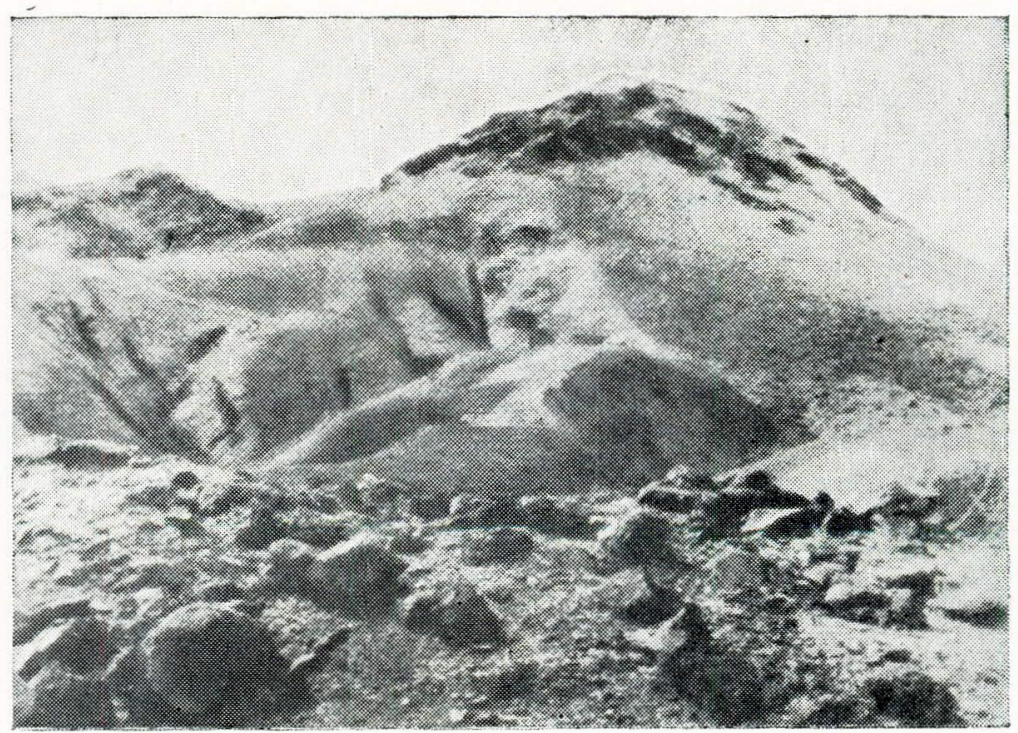

Hircânia-El Mird.

(Biblica 42 [1961] 16-17, Plate I). 
por vêzes em sentido mais largo, como colônias militares. Ainda mais, se o exército ptolomaico podia ser definido como exército sedentário (n. 396), uma parte destas colônias militares herodianas pode ser designada como um exército irregular e voluntário, que se reunia, por conta própria, em casos de perigo, e cuidava da defesa de suas pessoas e de seus interêsses, e, com êles, da segurança e paz interna do Estado.

401. - Em todo caso, deviam as colônias militares, de qualquer tipo que fôssem, e devido às vantagens materiais que proporcionavam aos contemplados, estimular grandemente o recrutamento de tropas, e garantir sua eficiência e fidelidade. Com efeito, consistindo grande parte dos colonos militares de veteranos estrangeiros e gentios (n. 394), ou, então, de tropas nacionais infensas até certo ponto aos judeus pròpriamente ditos, como os samaritanos (n. 349), ou particularmente devedores aos reis, como os judeus babilônicos da Batanéia (nn. 350. 392), podia esperar-se dêles um interêsse todo especial pela causa da monarquia. Se ajuntarmos a isto o interêsse pessoal que deviam ter como beneficiários da corôa, entendemos plenamente que as tropas dos sebastenos, cesarenos, traconítidas e babilônicos figuram entre as tropas fiéis à causa da monarquia e à causa romana (189) .

\section{(Continua no próximo número).}

\section{JOÃO MEHLMANN O.S.B.}

da Ponttfícia Universidade Católica de Sāo Paulo e Professor-visitante da Faculdade de Filosofia, Ciências e Letras da Universidade de São Paulo. 189). - Não faltam exceçōes a regra, como o caso de dois nobres traconitidas
que se bandearam com Jose, v. $23 \S 11$ s; o de Nóaro ou Varo, que in-
trigava contra Agripa II e os judeus babilonicos, G. 2, 18, 6 481-483; v.
11 $\S 48-61$; o de Silas, o babilônio, que combateu ao lado dos revoltosos
durante a guerra contra Roma, G. 2, 19, $2 \S 520 ; 3,2,1 \S 11$.

\section{SUPLEMENTO A BIBLIOGRAFIA.}

- (ver Número 42, Ano XI, Volume XX, 1960, 392s):

ABEL, F.-M., Les Ilvres de Maccabées, Parls 1949.

BIKERMAN, E., Institutions des Séleucides, Paris 1938.

FREY, J.-B., Corpus Inscriptionum Judalcarum, 2 vols., Città del Vaticano 1936-1952.

JONES, A. H. M., The Greek City from Alexander to Justinian, Oxford 1940.

JUSTER, J., Les juifs dans l'empire romain, 2 vols., Paris 1914.

PEROWNE, ST., The Life and Times of Herod the Great, London 1957.

TCHERIKOVER, V., Hellenistic Civllization and the Jews, Philadelphia 1959. 